\title{
Sistema de Gestão Ambiental (SGA) e aplicabilidade do Selo AQUA: estudos de casos em empresas construtoras de shopping centers
}

\author{
Environmental Management System (EMS) and applicability of \\ Seal AQUA: case studies in construction companies mall
}

\begin{abstract}
Andressa Guimarães Gomes andressaguimaraesgomes@ gmail.com Universidade de Fortaleza

Suellen Galvão Moraes suellengalvao_m@hotmail. com

Universidade de Fortaleza
\end{abstract}

\section{Márcia Thelma Rios Donato Marino \\ marino@unifor.br Universidade de Fortaleza}

\section{Denise Fernandes}

denisefernandes@unifor.br Universidade de Fortaleza

\section{Resumo}

A construção civil é uma das áreas que causa muitos impactos negativos ao meio ambiente, destacandose a grande geração de resíduos, sendo necessária a sua redução, que pode ser efetivada com a aplicação de sistemas de gestão ambiental (SGA) pelas empresas construtoras, buscando-se uma construção sustentável. O estudo trata da aplicação do SGA na construção de dois shoppings centers que obtiveram o Selo AQUA, compara e avalia o desempenho ambiental alcançado, considerando os níveis atingidos em cada fase da Certificação. A metodologia aplicada foi revisão bibliográfica, pesquisa documental e conversa com funcionários. Pode-se concluir que o empreendimento "B", que iniciou o processo de certificação e aplicou o SGA desde o planejamento, obteve melhor desempenho que o "A", que iniciou o processo na fase de execução. A geração de resíduos no empreendimento "A" foi significativamente maior que no "B", indicando desvantagens da aplicação do SGA a partir da fase de execução. Existe uma grande resistência em profissionais da área da construção civil, desde o colaborador ao diretor da obra, a respeito de práticas sustentáveis. A implantação do Sistema de Gestão Integrada - SGI entre os setores, o suporte através de efetivo, máquinas e equipamentos e as práticas de reuso e reutilização dos recursos no canteiro de obras adotados para o empreendimento "B", provam que o investimento é a chave para alcançar um bom desempenho ambiental. E todo esse investimento retorna para a empresa através da redução do consumo de recursos, redução da geração de resíduos, além de proporcionar melhorias ambientais e sociais.

Palavras-chave: Sistema de gestão ambiental; Selo AQUA; Shopping Center; Resíduos sólidos; Impactos ambientais.

\begin{abstract}
The civil construction is one of the areas that causes more impacts, both positive and negative, to the environment, even more by the great generation of waste. Given this scenario, it is necessary to reduce these impacts, which can be reached with the application of environmental management systems by construction companies, seeking sustainable construction throughout its production processes. This research shows a case study of the application of the Environmental Management System - EMS on the construction of two shopping malls that have obtained the AQUA certification, compares and evaluates the environmental performance achieved by the enterprises considering the achieved levels in each phase of certification AQUA. The theoretical-methodological approach was applied through literature review and documentary research, and, subsequent, study of virtual servers of enterprises and interviews with employees. It can be concluded that the enterprise B, which started the certification process and applied the EMS from planning phase, performed better than the enterprise A, who started the certification process from the execution phase, registering more difficult to implement the EMS. Officials attributed these difficulties to the reduced effective and lack of support from senior management. Waste generation in the enterprise A was significantly higher than in the enterprise B, -indicating the disadvantages of the implementation of the EMS only from the execution phase. The implementation of Integrated Management System - SGI across sectors, supported by effective machinery and equipment and practices of reusability and reuse of resources at the construction site adopted for the project $\mathrm{B}$, support the idea that the investment is the key to achieving good environmental performance. In addition, all this investment returns for the company by reducing the consumption of resources, reduction of waste generation, in addition to providing environmental and social improvements.
\end{abstract}

Keywords: Environmental management system. Certification AQUA. Shopping mall; Solid waste. Environmental impacts. 


\section{Introdução}

É notório que o comportamento consumista da sociedade atual, fruto do modelo capitalista adotado pela sociedade e maioria das empresas, está muito aquém de um modelo de crescimento socioeconômico sustentável, ou seja, aliado ao cuidado e respeito aos limites dos nossos sistemas ambientais. No ramo da construção civil, este fato não se apresenta diferente.

É marcante o descaso com o meio ambiente, o que pode estar associado à falta de informações no que diz respeito aos impactos ambientais decorrentes das práticas e técnicas construtivas utilizadas e, também, ao desconhecimento de ferramentas e metodologias de gestão que podem minimizar esses impactos, auxiliando as construtoras na implantação de um modelo sustentável de gestão.

Hoje a preocupação com essas questões já pode ser observada através das legislações desenvolvidas com a função de restringir emissões de poluentes, disposição de resíduos sólidos e líquidos, emissão de ruídos, exploração de recursos naturais, dentre outros. Diante desse cenário, é inerente a importância da adoção de novos critérios para a seleção de insumos a serem empregados nos empreendimentos, bem como novas formas de lidar com os resíduos gerados. Tornase imprescindível a evolução do setor da construção civil voltada à vertente ambiental do desenvolvimento sustentável.

O Sistema de Gestão Ambiental - SGA é um processo que busca solucionar ou mitigar problemas de aspectos ambientais. Os impactos antrópicos ao longo do tempo levaram a criação desse sistema, com o objetivo de reduzir ou mitigar os danos causados por diversas atividades. Conhecer as atividades que impactam negativamente e estudar como mitigá-las é fundamental para desenvolver e operar um bom sistema de gestão ambiental.

Aplicar o SGA, principalmente desde as etapas iniciais, pode trazer benefícios, como redução de gastos, obtenção de lucro, minimização do uso de recursos naturais, dentre outros. Portanto, entender todo o funcionamento do SGA é importante para observar onde e como ele pode ser aplicado, com suas devidas características variando de acordo com a organização ou empreendimento.

Os empreendimentos da construção civil são grandes causadores de impactos ao meio ambiente e o setor de construção de shopping centers ganha maior destaque, pois geralmente são empreendimentos de grande porte. Degani e Cardoso (2002) apresentam os elementos de conexão entre determinada fase do empreendimento e o meio ambiente. Apresentam também como maiores consequências desses investimentos a diminuição dos recursos naturais e a poluição causada em praticamente todas as fases de execução e também operação.

Outro impacto negativo que se faz presente nas diferentes fases do empreendimento é a poluição, que pode ser classificada como poluição da água, do solo, sonora ou atmosférica. A poluição sonora é sentida pelos funcionários e pelos moradores da vizinhança, causada na maioria das vezes pelos inúmeros equipamentos em funcionamento ao mesmo tempo no canteiro de obras. A poluição atmosférica é decorrente principalmente da emissão de material particulado na fase de execução e demolição, e também da emissão de $\mathrm{CO}_{2}$ proveniente de equipamentos ou de um possível incêndio. A poluição da água e do solo pode ser causada pelo descarte inadequado dos resíduos sólidos e líquidos. A poluição da água também pode ser ocasionada por vazamentos de óleo dentro do próprio canteiro de obra, isso é comum em caso de acidentes envolvendo os equipamentos ou manutenções realizadas no canteiro sem o uso de lonas de contenção sob os equipamentos. Caso as medidas mitigadoras não sejam tomadas esse óleo pode infiltrar no solo e atingir lençóis freáticos (DEGANI, 2003).

Dentre os pontos apresentados, os que ganham maior destaque são a exploração dos recursos naturais e o grande número de resíduos gerados que podem levar à poluição da água e do solo.

A maioria da matéria-prima utilizada na execução de obras é originada da extração de recursos naturais, por exemplo, madeira, ferro, gesso, areia, cimento, brita, dentre outros. É inviável construir um empreendimento sem explorar recursos naturais, o problema se encontra na forma como esses recursos são explorados e na quantidade. Outro problema comum percebido nesta pesquisa é o desperdício de materiais. De acordo com Paliari (1999), sempre que é preciso consumir uma quantidade maior de material do que realmente é necessário gera-se perda, que pode ser refletida através da compra de mais materiais, geração de mais resíduo, necessidade de mão-de-obra para refazer atividades e mais exploração de recursos. Essas perdas podem ser causadas devido à falta de planejamento e/ou falta de fiscalização no momento da execução dos serviços, gerando um retrabalho.

Segundo o Conselho Brasileiro de Construção Sustentável - CBCS, a construção civil consome de 40 a $75 \%$ dos recursos naturais extraídos em todo o mundo. Os principais impactos dessa grande exploração são a escassez e extinção 
das fontes e jazidas, além de alterações na fauna e flora da região explorada (DEGANI, 2003). Um exemplo desse esgotamento de recursos está em São Paulo, segundo John (2000), as jazidas de areia próximas a capital não mais conseguem atender a demanda, sendo transportados de jazidas a mais de $100 \mathrm{~km}$ de distância, gerando outros impactos através do transporte, pois é necessário mais consumo de combustível e em consequência mais emissões atmosféricas.

Para reduzir esses desperdícios se faz necessário a melhoria da etapa de planejamento, onde as tecnologias e materiais são selecionados, determinando o bom desempenho ambiental do empreendimento. No momento dessas escolhas diversas questões devem ser observadas, como durabilidade, preço, origem. Segundo Sjostrom (2000), não só o conhecimento específico da durabilidade do material é importante, mas também o funcionamento do conjunto por eles formado. Ele sugere que sejam utilizados dados sobre a vida útil dos empreendimentos, que podem ser obtidos através de informações de clientes ou outros empreendedores.

Pela ótica econômica, não gerenciar de forma adequada os resíduos sólidos é deixar de ganhar benefícios, pois diversos resíduos possuem um potencial de reuso ou reciclagem, capaz de gerar lucro. É a chamada valorização dos resíduos, definida como, operação efetuada a partir de resíduos, para aplicações úteis e em substituição a outras matériasprimas, ou na preparação de resíduos para que possam ser utilizados para este fim; podendo ser efetuada em usinas ou no âmbito da cadeia produtiva (FUNDAÇÃO VANZOLINI, 2010).

Do ponto de vista sanitário e ambiental uma gestão inadequada dos resíduos leva a riscos de contaminação de recursos naturais e em consequência acarretam problemas de saúde pública. Um aspecto que não foi citado, mas que também está incluído nessas questões é o social, a catação de resíduos sólidos para comercialização tem favorecido o desenvolvimento de uma atividade econômica que é a catação de resíduos em lixões e nas ruas por catadores, esta atividade na maioria das vezes não é realizada de forma adequada, pois os catadores trabalham muitas vezes informalmente, sem a devida regularização de suas atividades, exceto quando fazem parte de cooperativas.

Dados da Associação Brasileira de Empresas de Limpeza Pública e Resíduos Especiais (ABRELPE) revelam que, em 2014, foram gerados no Brasil aproximadamente 78,6 milhões de toneladas de resíduos sólidos urbanos (RSU), o que representa um aumento de $2,9 \%$ de um ano para o outro, índice superior à taxa de crescimento da população no país no período, que foi de $0,9 \%$. De modo geral, a produção de resíduos sólidos per capita tem aumentado a cada ano, o que demonstra que o Brasil ainda não adotou medidas de minimização na geração de resíduos.

A geração de RSU per capita variou de 379,96 kg/hab/ano em 2013 para 387,63 kg/hab/ano, ou seja, um aumento de $3,20 \%$. A comparação entre a quantidade de RSU gerada e a coletada em 2014 mostra que o País contou com um índice de cobertura de coleta de 90,6\%, levando à constatação de que pouco mais de 7 milhões de toneladas deixaram de ser coletadas no país neste ano e, consequentemente, tiveram destino impróprio. Em 2013 a coleta per capita equivalia a 343,46 kg/hab/ano e em 214 passou a ser 351,49 kg/hab/ano. (ABRELPE, 2014).

Ainda segundo a ABRELPE, em relação aos resíduos de construção e demolição (RCD), foram coletados pelos municípios 45 milhões de toneladas em 2014, o que implica no aumento de 4,1\% em relação a 2013. Esta situação, também observada em anos anteriores, exige atenção especial quanto ao destino final dado aos RCD, visto que a quantidade total desses resíduos é ainda maior, uma vez que os municípios, via de regra, coletam apenas os resíduos lançados nos logradouros públicos.

Dentro desse contexto estão inseridas construtoras de shoppings centers, responsáveis por obras de grande porte que impactam positiva e negativamente as áreas de seus empreendimentos, objetos de estudo desta pesquisa.

Esta pesquisa compara e avalia o desempenho ambiental alcançado na construção de shopping centers que obtiveram o Selo AQUA, a partir da aplicação do Sistema de Gestão Ambiental - SGA em diferentes fases (planejamento ou execução) do empreendimento. Além de quantificar e comparar a geração de resíduos nos dois empreendimentos; Analisar o desempenho ambiental dos empreendimentos, considerando os níveis em cada fase da Certificação AQUA para a Categoria 3; e analisa em qual fase do empreendimento, planejamento ou execução, a aplicação do Sistema de Gestão Ambiental (SGA) é mais eficiente.

\section{Metodologia}

Este estudo possui cunho cientifico-acadêmico, trata-se de uma pesquisa do tipo quali-quantitativa, pautada na abordagem descritiva, caracterizado pela descrição e avaliação de programas de gestão ambiental (SGA) de dois grandes shoppings centers. 
O trabalho apresenta-se como um estudo de caso. Segundo Yin (2015), o estudo de caso é aplicado quando se deseja responder as perguntas: como ou por que. O método é relevante ainda quando a questão exigir uma descrição ampla e profunda de algum fenômeno, usado para contribuir ao conhecimento de fenômenos individuais, grupais, organizacionais, sociais, políticos e relacionados.

O caso desta pesquisa refere-se à avaliação da aplicabilidade de sistema de gestão ambiental por empresas construtoras de dois shoppings centers de grande porte, instalados na região nordeste do Brasil, desde o início do planejamento, passando por toda a execução dos empreendimentos.

Trata-se ainda de uma pesquisa documental e bibliográfica, fundamentada em artigos científicos, livros, dissertações e teses que contribuíram para esclarecer conceitos importantes, permitindo melhor compreensão da pesquisa.

A coleta das informações necessárias para os estudos de caso foi realizada da seguinte forma: a) estudo do servidor virtual de cada empreendimento, onde todas as informações ligadas ao sistema de gestão ambiental Encontram-se em um banco de dados para disponível para consultas; b) conversas com os responsáveis pela elaboração e alimentação do servidor referente ao empreendimento "A", além da experiência efetiva na elaboração e alimentação do servidor referente ao empreendimento "B"; e c) análise dos Sistemas de Gestão Ambiental dos dois empreendimentos para obtenção do Selo AQUA.

\section{Resultados e discussão}

A expressão gestão ambiental pode ser entendida como as diretrizes e atividades administrativas e operacionais que têm como objetivo obter efeitos positivos sobre o meio ambiente (BARBIERI, 2007). Alguns estudiosos têm afirmado que a utilização da gestão ambiental pelas empresas tem propiciado diversos benefícios, tais como baixos custos e conquistas de mercado (GUPTA, 1994; PORTER; SHRIVASTAVA, 1995; TACHIZAWA, 2002; SALAZAR FILHO, 2002; WILNER, 2006; MANO, 2008).

Assim, é possível entender o Sistema de Gestão Ambiental - SGA como o processo utilizado com o objetivo de resolver, mitigar e prevenir problemas relacionados às questões ambientais.

O SGA faz parte de um sistema maior que é o sistema de gestão, através dele é possível compreender a estrutura organizacional de uma empresa, quais práticas ela executa, quais seus procedimentos, suas responsabilidades, como funcionam seus processos e quais tipos de recursos são utilizados para manter a política ambiental da empresa.

Assim, é fundamental que os objetivos e metas que desejam ser alcançados sejam claramente definidos e comunicados para todos os setores envolvidos. Caso não haja uma definição exata dos objetivos e metas não será possível gerenciar de forma efetiva e organizada o SGA.

A certificação ambiental é um instrumento utilizado pelas empresas como um parâmetro de análise que o consumidor pode utilizar como referência sobre o histórico ambiental daquela determinada organização em relação aos impactos positivos e negativos sobre o meio ambiente e a sociedade. O processo de certificação ambiental garante ao consumidor a segurança ambiental pela qual o produto ou serviço passou durante sua execução.

Além de promover a imagem da organização e atrair clientes conscientes, a certificação aparece juntamente com programas ambientais que dão diretrizes para que o processo produtivo e de logística, seja mais eficiente no ponto de vista econômico.

A certificação ambiental mais conhecida e difundida é a ISO 14.000. A família ISO 14000 aborda vários aspectos da gestão ambiental. As primeiras duas normas, ISO 14001:2004 e ISO 14004:2005 lidam com Sistemas de Gestão Ambiental (SGA). A ISO 14001:2004 fornece os requisitos para um SGA e a ISO 14004:200 fornece orientações gerais para um SGA.

$\mathrm{Na}$ área de construção civil, destacam-se as seguintes certificações ambientais: AQUA (Alta qualidade Ambiental), LEED (Leadership in Energy and Environmental Design) e Procel Edifica.

Parar efeitos desta pesquisa definiu-se a certificação AQUA como objeto de estudo aplicado aos empreendimentos escolhidos.

\subsection{Certificação AQUA}

O processo AQUA (Alta Qualidade Ambiental) decorreu da francesa Démarche HQE. É um Processo de Gestão Total do Projeto para obter a Alta Qualidade Ambiental do seu Empreendimento de Construção. Essa qualidade é demonstrada para seus clientes, investidores e demais partes interessadas por meio da certificação. A certificação e a 
marca Processo AQUA são concedidas pela Fundação Vanzolini, com base em auditorias presenciais independentes (FUNDAÇÃO VANZOLINI, 2015).

O selo AQUA - Alta Qualidade Ambiental é o referencial técnico brasileiro para construções sustentáveis, concedido pela Fundação Vanzolini. Este selo é uma assinatura verde para o mercado, atraente para, por exemplo, construtoras e incorporadoras, que vão afirmar o compromisso do incorporador com a sociedade e o meio ambiente.

Este selo é internacionalmente conhecido e, na Europa, garante uma valorização até $30 \%$ acima do mercado para empreendimentos certificados. Assim, com a conquista deste selo os incorporadores comprovam que estão atendendo as exigências ambientais em todo o processo de planejamento e execução de um empreendimento (FUNDAÇÃO VANZOLINI, 2015).

Para iniciar a certificação dos edifícios brasileiros com o selo internacional AQUA, que é inspirado no selo francês HQE, os professores do Departamento de Engenharia Civil e Produção da Escola Politécnica da Universidade de São Paulo (USP), em conjunto com consultores, adequaram as exigências do Referencial Técnico francês ao contexto da construção civil brasileira (FUNDAÇÃO VANZOLINI, 2015).

Antes do surgimento desse referencial técnico brasileiro a única possibilidade de conseguir um selo de reconhecimento internacional para os empreendimentos no Brasil, era recorrendo ao certificado norte-americano do Green Building Council, o LEED - Leadership in Energy and Environmental Design.

No entanto, existem diversos pressupostos e critérios relacionados ao clima, legislação e fontes de energia, que nem sempre condizem com as condições climáticas do nosso país. Por isso esse trabalho de adequação tornou possível a chegada da certificação AQUA ao Brasil.

No Brasil, nos critérios determinados para conquistar a certificação AQUA, é necessário definir o Perfil Ambiental do Empreendimento, a partir da explicitação das prioridades do empreendedor, em relação à Qualidade Ambiental almejada para o Empreendimento, denominado QAE (FUNDAÇÃO VNZOLINI, 2015).

O Perfil organiza e hierarquiza as preocupações ambientais, expressas nas 14 categorias de desempenho, e explica requisitos para os quais os envolvidos no desenvolvimento do empreendimento devem atentar. Devem participar da definição do Perfil o empreendedor ou o seu representante, em conjunto com a equipe de projetistas, e devem ser considerados (FUNDAÇÃO VANZOLINI, 2010):

- Atendimento às leis, normas e regulamentos;

- Atendimento às expectativas dos investidores/acionistas;

- Respeito às características locais, a partir do diagnóstico realizado.

Para cada uma das 14 categorias, Tab. (01), deve ser definido qual o nível de desempenho que se pretende alcançar: Bom (normativo; correspondente ao atendimento do desempenho mínimo exigido em normas técnicas e leis vigentes, e às boas práticas), Superior ou Excelente (melhores práticas). Para a obtenção do certificado AQUA, faz-se necessário que pelo menos três categorias sejam classificadas no nível Excelente de desempenho e no máximo sete categorias no nível Bom (FUNDAÇÃO VANZOLINI, 2010).

Tabela 01: Categorias Certificação AQUA.

\begin{tabular}{|l|l}
\hline FAMÍLIA & CATEGORIA \\
\hline Eco construção & $\begin{array}{l}\text { Categoria 1: Relação do edifício com o seu entorno } \\
\text { Categoria 2: Escolha integrada de produtos, sistemas e processos construtivos } \\
\text { Categoria 3: Canteiro de obras com baixo impacto ambiental }\end{array}$ \\
\hline Gestão & $\begin{array}{l}\text { Categoria 4: Gestão de energia } \\
\text { Categoria 5: Gestão da água } \\
\text { Categoria 6: Gestão do resíduo de uso e operação do edifício } \\
\text { Categoria 7: Manutenção - Permanência do desempenho ambiental }\end{array}$ \\
\hline Conforto & $\begin{array}{l}\text { Categoria 8: Conforto higrotérmico } \\
\text { Categoria 9: Conforto acústico } \\
\text { Categoria 10: Conforto visual } \\
\text { Categoria 11: Conforto olfativo }\end{array}$ \\
\hline Saúde & $\begin{array}{l}\text { Categoria 12: Qualidade sanitária dos ambientes } \\
\text { Categoria 13: Qualidade sanitária do ar } \\
\text { Categoria 14: Qualidade sanitária da água }\end{array}$ \\
\hline
\end{tabular}

Fonte: Gomes, 2015. 
A certificação AQUA é concedida em cada uma das fases do processo de produção de um empreendimento programa, concepção e realização, mediante uma auditoria presencial, na qual são confrontadas as soluções de projeto face ao nível de desempenho almejado pelo empreendedor.

Para o desenvolvimento da documentação necessária às auditorias, que compõe o processo de Certificação AQUA, deve ser designado um profissional responsável, que atuará como representante do empreendedor, ou deve ser contratada uma assessoria específica para tal finalidade, durante todas as fases do empreendimento, citadas abaixo:

a) Programa: fase durante a qual se elabora o programa de necessidades, documento destinado aos projetistas para a concepção arquitetônica e técnica de um empreendimento;

b) Concepção: fase durante a qual os projetistas, com base nas informações do programa, elaboram a concepção arquitetônica e técnica de um empreendimento; e

c) Realização: fase durante a qual os projetos são construídos, tendo como resultado final a construção de um empreendimento.

Neste trabalho será destacada a Categoria 3, que é descrito na Tab. 02 a seguir:

Tabela 02: Critérios da Categoria 3 - Certificação AQUA.

\section{CRITÉRIOS DE AVALIAÇÃO}

3.1.1. Otimizar a coleta, a triagem e o agrupamento dos resíduos do canteiro

3.1 Otimização da gestão dos resíduos do canteiro de obras

3.2 Redução dos incômodos causados pelo canteiro de obras

3.3 Redução da poluição e do consumo de recursos no canteiro de obras

3.4 Construção de aspectos sociais no canteiro de obras

\section{de obras}

3.1.2. Beneficiar o máximo possível os resíduos de canteiro e de forma coerente com as cadeias locais existentes, bem como garantir a correta destinação destes resíduos

3.1.3 Minimizar a produção de resíduos do canteiro de obras na fonte

3.2.1. Limitar os incômodos sonoros

3.2.2. Limitar os incômodos visuais

3.2.3 Limitar os incômodos devidos à circulação de veículos

3.2.4 Limitar os incômodos devidos ao material particulado, à lama, aos derramamentos de concreto

3.3.1. Limitar a poluição da água e do solo

3.3.2. Limitar a poluição do ar

3.3.3 Limitar o consumo de recursos

3.4.1. Limitar riscos sanitários

3.4.2. Estimular a formalidade na cadeia produtiva da construção civil

Fonte: Adaptado de Fundação Vanzolini, 2010.

\subsubsection{Caracterização dos Empreendimentos}

A intenção deste estudo de caso é avaliar a implantação do SGA, em dois empreendimentos semelhantes que passaram por um processo de certificação a partir de fases distintas do empreendimento, bem como identificar as vantagens apresentadas por cada um e seu desempenho para a obtenção da certificação AQUA.

Para tanto, faz-se necessário a caracterização e descrição dos dois empreendimentos (A e B) pesquisados, além de apresentar as ações desenvolvidas para implantação do Sistema de Gestão Ambiental (SGA) pelas construtoras em busca do Selo AQUA - Alta Qualidade Ambiental e, por fim, definir o desempenho ambiental obtido através do SGA que foi implantado pelas empresas construtoras.

As discussões foram pautadas nas observações in loco e nas análises e interpretações dos resultados dos documentos analisados, com foco na avaliação da efetividade da aplicação do Sistema de Gestão Ambiental (SGA).

O empreendimento "A" refere-se à construção de um edifício destinado ao serviço comercial, shopping center, localizado em uma capital nordestina. Segundo o Projeto Arquitetônico, esse shopping contou com uma estrutura multipiso com elementos estruturais pré-moldados de concreto e estruturas metálicas, sendo formado por 5 pavimentos e um edifício garagem, erguidos em um terreno de 202.710,70 $\mathrm{m}^{2}$. Os 5 pavimentos são divididos em E1 (área de 
estacionamento), L1, L2, L3 e L4 (áreas de loja), e o edifício garagem é chamado de Deck Park. Todos os pavimentos resultam em $237.719 \mathrm{~m}^{2}$, área construída do empreendimento.

A área de estacionamento, composta pelo E1 e Deck Park, contém 6.091 vagas, totalizando uma área de 95.119,25 $\mathrm{m}^{2}$. Os pavimentos L1, L2, L3 e L4, são formados por áreas de mall, holl e 476 lojas, correspondentes a 142.599,75 m².

O empreendimento foi executado em um período de 25 meses, iniciado em outubro de 2010 e inaugurado em outubro de 2012. Porém, o processo de certificação se deu somente na fase de execução do empreendimento. Durante a execução, a obra montou uma estrutura para o desenvolvimento dos trabalhos administrativos e do planejamento da obra, Área Administrativa, onde foram construídas salas para cada setor. No decorrer da obra, também foi instalado um ponto de apoio para área comercial e comitê lojista.

O empreendimento "B" também se refere à construção de um shopping center, edifício destinado ao serviço comercial, localizado também em uma capital nordestina. Conforme a tipologia apresentada, esse shopping é formado por 6 pavimentos e um edifício garagem, constituído por uma estrutura multipiso com elementos estruturais pré-moldados de concreto e estruturas metálicas, erguidos em um terreno de 114.030,48 $\mathrm{m}^{2}$.

Os 6 pavimentos são divididos em E1 e E2 (áreas de estacionamento), L1, L2, L3 e L4 (áreas de loja). O edifício garagem com 9 pavimentos, divididos em E1, E2, E3, E4, E5, E6, E7, E8 e E9, é chamado de Deck Park. Todos os pavimentos resultam em $307.376,31 \mathrm{~m}^{2}$ de área construída do empreendimento.

A área de estacionamento é composta pelo E1, E2 e Deck Park e contém ao todo 6.392 vagas, enquanto os pavimentos L1, L2, L3 e L4, são formados por áreas de mall, holl e 373 lojas.

Os pavimentos E1 e E2 formam os dois primeiros pavimentos completos. Os pavimentos E4, E6 e E8 são lajes de mezanino do Deck Park existentes entre os pavimentos L1 e L2, L2 e L3, L3 e L4, respectivamente. Os pavimentos E3, E5, E7 e E9 do Deck Park se ligam, respectivamente, aos pavimentos L1, L2, L3 e L4.

Também foi executado em um período de 25 meses, com início em outubro de 2012 e inauguração em outubro de 2014.

Para o desenvolvimento dos trabalhos administrativos e planejamento da obra, também foram construídas salas para cada setor, assim como um ponto de apoio para área comercial e comitê lojista.

Os impactos negativos mais significativos e comuns em um canteiro são referentes à gestão de resíduos, consumo de recursos, riscos sanitários, poluição da água, do solo e do ar, e ainda, incômodos sonoros, visuais ou devido ao aumento e circulação de veículos. As ações que serão citadas neste tópico são essenciais para reduzir esses impactos ambientais decorrentes das atividades das construtoras no canteiro de obras, levando em consideração as premissas do Selo AQUA - Alta Qualidade Ambiental.

As ações que foram desenvolvidas conforme as exigências da Categoria 3 - Canteiro de obras com baixo impacto ambiental foram descritas separadamente de acordo com cada critério de avaliação.

Os consultores e auditores orientam que o ideal é que o processo de certificação tenha início ainda na fase de planejamento. Dentre os dois empreendimentos escolhidos para o estudo de caso, o primeiro empreendimento buscou o processo de certificação durante a fase de execução e o segundo deu início ao processo ainda na fase de planejamento.

Conforme a avaliação da Categoria 3, o primeiro item é o 3.1 - Otimização da gestão dos resíduos do canteiro de obras, onde o primeiro critério de avaliação é o 3.1.1 - Otimizar a coleta, triagem e o agrupamento dos resíduos do canteiro de obras. Esse critério prevê a quantificação prévia por tipo de resíduo, bem como as medidas tomadas para coletar, triar e sinalizar os resíduos gerados de acordo com sua classificação, a fim de facilitar a retirada dos resíduos, impedindo a sua mistura. O critério também exige a elaboração de plano de gerenciamento dos resíduos do canteiro e a adoção de prescrições contratuais a serem mantidas com as empresas contratadas para as atividades de execução no canteiro.

Para atender esse critério, primeiramente foi realizada uma estimativa de geração e valorização de resíduos e elaborado o Plano de Gerenciamento de Resíduos Sólidos - PGRS. Também foram criadas duas centrais de triagem de resíduos que ficavam localizadas no térreo, uma composta por caçambas do tipo contêiner (Fig. 01) e outra de alvenaria, formada por compartimentos (Fig. 02), para armazenamento dos resíduos, fornecidas pela própria empresa que realizava a coleta, transporte e destinação final. 
Figura 01: Contêineres coletores de resíduos.

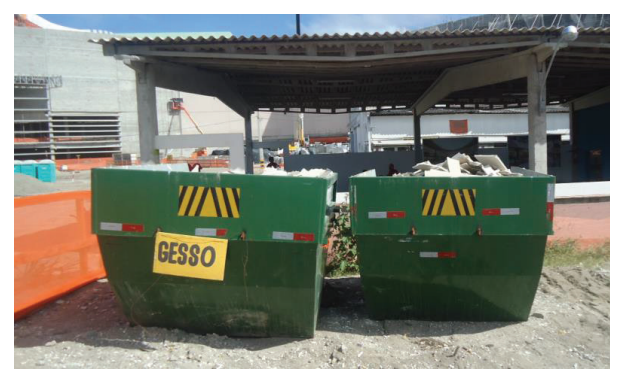

Fonte: Gomes, 2015 .
Figura 02: Baias de alvenaria.

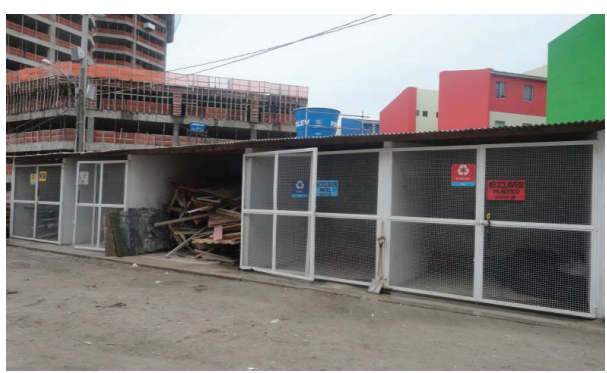

Fonte: Gomes, 2015.

Como foi mencionado, o processo de certificação só teve início na fase de execução, onde inúmeras empresas já haviam sido contratadas, portanto a cláusula referente à exigência do critério 3.1.1 não foi inclusa em diversos contratos do empreendimento "A".

O critério 3.1.2 - Beneficiar o máximo possível os resíduos de canteiro e de forma coerente com as cadeias locais existentes, bem como garantir a correta destinação destes resíduos, exige que as cadeias de transporte e destinação de cada tipo de resíduo sejam analisadas do ponto de vista técnico, ambiental e econômico, procurando selecionar a melhor opção de beneficiamento e valorização. Também exige que seja emitido o Manifesto de Transporte de Resíduos MTR, dito como formulários de controle de transporte de resíduos, para todos os resíduos que saem da obra, sejam eles controlados (perigosos) ou não controlados (construção e desconstrução).

Para os resíduos controlados é necessário escolher um destinador que esteja em conformidade com as questões legais e, quando a produção for superior a 1100 litros/semana, deve ser feito o beneficiamento de $100 \%$ desses resíduos (reutilização ou fonte de energia).

Para os resíduos controlados são atribuídos níveis como meta a ser atingida através do percentual de valorização, como mostra a Fig. 03:

Figura 03: Percentual de valorização.

$\begin{array}{ll}\text { Construção } & \\ \text { - } 30 \% & \mathrm{~B} \\ \text { - } 40 \% & \mathrm{~S} \\ \text { - } 50 \% & \mathrm{E} \text { (3 pontos) } \\ \text { - } 70 \% & \mathrm{E} \text { (6 pontos) }\end{array}$

Fonte: Fundação Vanzolini, 2010.

A cadeia de beneficiamento e valorização de resíduos próximos a localização do empreendimento " $\mathrm{A}$ " era bem desenvolvida, o que possibilitou que esse empreendimento alcançasse um bom percentual de valorização, onde somente o lixo comum e o resíduo perigoso não eram valorizados. O lixo comum era encaminhado para aterro e o perigoso para incineração. O processo de incineração dos resíduos perigosos não gerava energia, pois não havia empresa que realizasse esse tipo de serviço próximo à localização desse empreendimento.

Entravam no percentual de valorização: madeira, metal, papel, plástico, orgânico, entulho e gesso. A madeira era enviada para reutilização, o metal era encaminhado para usinas de reciclagem, o orgânico era enviado para empresa que o transformava em adubo, o gesso era processado e voltava a ser matéria-prima, o entulho era encaminhado para empresa que também realizava o processo para que pudesse ser utilizado como matéria-prima para a construção civil, o papel e o plástico eram enviados para empresas que faziam a triagem desses resíduos e os submetiam ao processo de reciclagem compatível com cada tipo de material.

Todos os MTRs e medições eram arquivados no final de cada mês. Através dos MTRs foi desenvolvida uma planilha de controle de resíduos para calcular os quantitativos gerados e sua valorização, a fim de verificar se as metas estavam sendo atingidas. No entanto, por ter sido implantada tardiamente, houve dificuldades na alimentação da planilha com os dados retroativos ao período de implantação do controle (meses anteriores). 
O critério 3.1.3 - Minimizar a produção de resíduos do canteiro de obras na fonte, prevê a minimização de geração de resíduos através de cláusula contratual, das medidas de gestão e organização do canteiro e dos processos construtivos praticados.

Como foi mencionado anteriormente, o processo de certificação só teve início na fase de execução, onde inúmeras empresas já haviam sido contratadas, portanto a cláusula referente a exigência do critério 3.1.3 não foi inclusa em diversos contratos do empreendimento " $\mathrm{A}$ ".

Para incentivar a não geração, a redução da geração e a reutilização de resíduos foram realizados treinamentos e campanhas sobre temas referentes aos critérios da Categoria 3 e apresentados cartazes informativos e de sensibilização para os colaboradores.

A escolha dos materiais que são utilizados também é importante na questão da minimização da geração de resíduos. Nessa situação, podemos perceber como se aplica o Sistema de Gestão Integrado - SGI, onde outros setores, como o da qualidade e o de compras, trabalhando junto ao setor de meio ambiente trazem ganho econômico e ambiental para a construção. O setor de qualidade verifica o andamento das atividades e a qualidade dos produtos usados, garantindo uma execução correta dos serviços e durabilidade dos materiais, evitando retrabalhos e problemas posteriores, colaborando com a redução da geração de resíduos e no uso de matéria-prima. O setor de compras, por sua vez, tem importância na relação do custo-benefício, no uso de materiais com grau de toxicidade e na redução do uso de materiais potencialmente poluidores.

Procurando atender esse critério, o empreendimento "A" usou estrutura multipiso com elementos estruturais prémoldados de concreto e estruturas metálicas. O processo mais tradicional faz uso de madeira ou ferro para montar a forma da estrutura e uso de concreto para fabricação da estrutura no momento da implantação. Já o uso de pré-moldados, além de garantir um canteiro de obra mais limpo, por gerar menos resíduos que o processo mais tradicional, também agiliza o processo construtivo, garante mais qualidade e maior longevidade ao empreendimento, que são os benefícios mais conhecidos.

O empreendimento " $A$ " não apresentava o setor de qualidade, o que resultou em desperdícios de materiais por erros de execução de serviços, atividades de retrabalho e desconstrução, aumentando os custos, a utilização de recursos naturais e a geração de resíduos. Os dados referentes à geração de resíduos foram registrados de janeiro de 2011 a novembro de 2012, totalizando 23 meses. Apesar de a inauguração do empreendimento tenha ocorrido no mês de outubro/2012, a geração perdurou por mais um mês devido à continuidade de algumas atividades.

$\mathrm{Na}$ fase de execução da obra, houve uma grande geração de resíduos. Durante o primeiro ano de construção, foi acumulado muito resíduo no canteiro, o que justifica os baixos índices na planilha de geração de resíduos, apresentados na Tab. (03), do empreendimento "A".

Ainda na Tab. (03) é possível observar índices maiores de geração de resíduos nos meses finais de 2012. Nesse período, houve chegada dos lojistas que são pessoas responsáveis pelas obras de cada loja, chegada dos funcionários responsáveis pela operação do shopping, início do abastecimento das lojas, o que gera grande quantidade de resíduos oriundos das embalagens que trazem os produtos para as lojas.

Como visto na Tab. (03), o número total de resíduos gerados foi de $78.351 .185 \mathrm{Kg}$, o que equivale a $329,59 \mathrm{~kg} / \mathrm{m}^{2}$, resultante do somatório da geração de madeira, metal, papel/plástico, lixo comum, orgânico, entulho, gesso e perigoso. A minimização de geração de resíduos, prevista pelo critério 3.1.3, não foi muito bem atendida.

Em relação à valorização dos resíduos, prevista no critério 3.1.2, o empreendimento " $\mathrm{A}$ ", possui certa vantagem por estar localizado em uma capital onde esses serviços são mais desenvolvidos. Os resíduos valorizados recebiam uma destinação mais nobre, sendo encaminhados para reutilização ou reciclagem. O lixo comum, por sua vez, era encaminhado para aterro, portanto não era valorizado, e o perigoso para incineração. O processo de incineração dos resíduos perigosos do empreendimento "A" não produzia energia, por isso não entrava na valorização de resíduos. A Tabela 04, a seguir, apresenta os percentuais de valorização referentes aos anos de 2011 e 2012.

Observa-se um excelente nível de valorização entre janeiro de 2011 e setembro de 2012, mas em outubro e novembro do último ano os resíduos não receberam a devida segregação, como é exigido no critério 3.1.1. Grande parte desses resíduos foram retirados da obra recebendo a classificação de lixo comum e encaminhados para aterro, reduzindo significativamente o percentual de valorização que chegou a 4,2\% em outubro e $0,0 \%$ em novembro. 
Tabela 03: Geração de resíduos referente ao ano de 2011 e 2012 no empreendimento "A”.

\begin{tabular}{c|c|c|c|c|c|c|c|c|c}
\hline \multicolumn{1}{|c|}{ GERENCIAMENTO DE RESIDUOS } & EMPREENDIMIENTO A - 2011 e 2012 \\
\hline MÊS & $\begin{array}{c}\text { MADEIRA } \\
\text { (KG) }\end{array}$ & $\begin{array}{c}\text { METAL } \\
\text { (KG) }\end{array}$ & $\begin{array}{c}\text { PAPEL/ } \\
\text { PLÁSTICO } \\
\text { (KG) }\end{array}$ & $\begin{array}{c}\text { LIXO } \\
\text { COMUM } \\
\text { (KG) }\end{array}$ & $\begin{array}{c}\text { ORGÂNICO } \\
\text { (KG) }\end{array}$ & $\begin{array}{c}\text { ENTULHO } \\
\text { (KG) }\end{array}$ & $\begin{array}{c}\text { GESSO } \\
\text { (KG) }\end{array}$ & $\begin{array}{c}\text { PERIGOSO } \\
\text { (KG) }\end{array}$ & $\begin{array}{c}\text { TOTAL } \\
\text { (KG) }\end{array}$ \\
\hline JAN/11 & 0 & 0 & 0 & 0 & 95.000 & 0 & 0 & 1.053 & 96.053 \\
FEV/11 & 6.217 & 4.020 & 0 & 40.220 & 65.000 & 404.550 & 0 & 0 & 520.007 \\
MAR/11 & 2.450 & 0 & 0 & 110.240 & 57.000 & 1.150 .140 & 0 & 616 & 1.320 .446 \\
ABR/11 & 17.720 & 0 & 0 & 90.200 & 69.000 & 941.400 & 0 & 0 & 1.118 .320 \\
MLA/11 & 26.760 & 0 & 0 & 1.920 & 63.000 & 280.065 & 0 & 78 & 371.823 \\
JUN/11 & 21.298 & 0 & 1.517 & 235.500 & 88.000 & 393.120 & 0 & 0 & 739.435 \\
JUL/11 & 20.050 & 0 & 402 & 64.610 & 36.800 & 840.420 & 0 & 1.181 & 963.463 \\
AGO/11 & 41.400 & 11.320 & 480 & 12.420 & 36.560 & 2.219 .520 & 0 & 0 & 2.321 .700 \\
SET/11 & 49.070 & 4.200 & 1.265 & 15.430 & 19.150 & 2.149 .560 & 0 & 1.500 & 2.240 .175 \\
OUT/11 & 36.630 & 8.400 & 1.376 & 19.930 & 19.150 & 1.732 .965 & 0 & 951 & 1.819 .402 \\
NOV/11 & 50.033 & 2.150 & 870 & 20.400 & 13.950 & 170.100 & 0 & 0 & 257.503 \\
DEZ/11 & 51.300 & 1.820 & 1.483 & 22.950 & 22.950 & 0 & 0 & 648 & 101.151 \\
JAN/12 & 110.375 & 14.010 & 3.220 & 31.080 & 21.750 & 3.894 .000 & 1.080 & 610 & 4.076 .125 \\
FEV/12 & 44.290 & 8.570 & 4.916 & 29.360 & 15.750 & 0 & 2.840 & 640 & 106.366 \\
MAR/12 & 77.920 & 9.530 & 4.374 & 32.310 & 6.200 & 7.639 .500 & 0 & 37.580 & 7.807 .414 \\
ABR/12 & 102.480 & 27.510 & 4.587 & 74.160 & 0 & 11.682 .000 & 20.670 & 887 & 11.912 .294 \\
MAI/12 & 120.670 & 11.760 & 1.583 & 66.440 & 0 & 3.993 .000 & 18.920 & 1.012 & 4.213 .385 \\
JUN/12 & 136.580 & 13.220 & 3.410 & 83.870 & 0 & 1.518 .000 & 45.030 & 42.310 & 1.842 .420 \\
JUL/12 & 131.280 & 17.280 & 2.495 & 90.110 & 0 & 7.755 .000 & 57.030 & 25.988 & 8.079 .183 \\
AGO/12 & 115.820 & 15.385 & 3.332 & 97.340 & 0 & 11.973 .000 & 54.810 & 43.580 & 12.303 .267 \\
SET/12 & 184.300 & 32.275 & 3.698 & 133.830 & 0 & 13.282 .500 & 84.390 & 990 & 13.721 .983 \\
OUT/12 & 38.880 & 0 & 350 & 2.277 .330 & 0 & 0 & 59.590 & 880 & 2.377 .030 \\
NOV/12 & 0 & 0 & 0 & 42.240 & 0 & 0 & 0 & 0 & 42.240 \\
\hline
\end{tabular}

Fonte: Gomes, 2015.

Com o avanço da obra, novos colaboradores foram contratados para as atividades de campo, mas não foi o suficiente para desenvolver a segregação dos resíduos de forma adequada em um período de geração intensa. Em relação ao corpo técnico, o efetivo se manteve, dificultando o controle e fiscalização dessas atividades, o que justifica a falta de segregação e o acentuado declínio do percentual de valorização.

No item 3.2 - Redução dos incômodos causados pelo canteiro de obras, o primeiro critério de avaliação é o 3.2 .1 Limitar os incômodos sonoros, que exige a identificação e caracterização das origens dos ruídos, bem como a elaboração de estratégias para a redução desses incômodos sonoros e a garantia do respeito ao nível de ruído máximo permitido ao entorno do canteiro. Também prevê a realização de estudo de acústica, a adoção de técnicas construtivas minimizadoras dos incômodos sonoros e o uso de materiais e máquinas em conformidade com a regulamentação, com as orientações dos fabricantes e em boas condições. 
Tabela 04: Percentual de valorização de resíduos referentes a 2011 e 2012 no empreendimento "A".

\begin{tabular}{|c|c|c|c|}
\hline \multicolumn{4}{|c|}{ PERCENTUAL DE VALORIZAÇÃO DE RESIDUOS - EMPREENDIMENTO A } \\
\hline MÊS & $\begin{array}{l}\text { TOTAL DE RESÍDUOS } \\
\text { GERADOS (KG) }\end{array}$ & $\begin{array}{l}\text { TOTAL DE RESÍDUOS } \\
\text { VALORIZADOS (KG) }\end{array}$ & $\begin{array}{l}\text { PERCENTUAL DE } \\
\text { VALORIZAÇÃO }(\%)\end{array}$ \\
\hline $\mathrm{JAN} / 11$ & 96.053 & 95.000 & 98,9 \\
\hline FEV/11 & 520.007 & 479.787 & 92,3 \\
\hline MAR/11 & 1.320 .446 & 1.209 .590 & 91,6 \\
\hline ABR/11 & 1.118 .320 & 1.028 .120 & 91,9 \\
\hline MAI/11 & 371.823 & 369.825 & 99,5 \\
\hline JUN/11 & 739.435 & 503.935 & 68,2 \\
\hline JUL/11 & 963.463 & 897.672 & 93,2 \\
\hline AGO/11 & 2.321 .700 & 1.309 .280 & 99,5 \\
\hline SET/11 & 2.240 .175 & 2.223 .245 & 99,2 \\
\hline OUT/11 & 1.819 .802 & 1.798 .921 & 98,9 \\
\hline NOV/11 & 257.503 & 237.103 & 92,1 \\
\hline $\mathrm{DEZ} / 11$ & 101.151 & 77.553 & 76,7 \\
\hline JAN/12 & 4.076 .125 & 4.044 .435 & 99,2 \\
\hline FEV/12 & 106.366 & 76.366 & 71,8 \\
\hline MAR/12 & 7.807 .414 & 7.737 .524 & 99,1 \\
\hline $\mathrm{ABR} / 12$ & 11.912 .294 & 11.837 .247 & 99,4 \\
\hline MAI/12 & 4.213 .385 & 4.145 .933 & 98,4 \\
\hline JUN/12 & 1.842 .420 & 1.716 .240 & 93,2 \\
\hline JUL/12 & 8.079 .183 & 7.963 .085 & 98,6 \\
\hline AGO/12 & 12.303 .267 & 12.162 .347 & 98,9 \\
\hline SET/12 & 13.721 .983 & 13.587 .163 & 99,0 \\
\hline OUT/12 & 2.327 .030 & 99.700 & 4,2 \\
\hline NOV/12 & 43.240 & 0,0 & 0,0 \\
\hline \multicolumn{4}{|c|}{ MÉDIA: $85,3 \%$} \\
\hline
\end{tabular}

Fonte: Gomes, 2015.

O empreendimento realizou o estudo de acústica, conhecido como medição de ruído, que são avaliações realizadas normalmente por empresas terceirizadas para informar se os ruídos do canteiro de obra estão no limite permitido de acordo com as normas, para não prejudicar os funcionários e a circunvizinhança.

Era realizada a manutenção das máquinas e equipamentos para que não emitissem ruídos capazes de prejudicar os funcionários. Os horários de funcionamento também eram controlados para que as atividades que emitissem ruído significativo não fossem executadas em horários impróprios.

O empreendimento também disponibilizou para a circunvizinhança um telefone para contato com o setor social, que recebe formalmente a reclamação e a repassa para o setor responsável pela solução do problema.

O critério 3.2.2 - Limitar os incômodos visuais exige que seja feita a limpeza semanal do canteiro e de suas periferias. Também devem ser cumpridas as recomendações sanitárias municipais, bem como a adoção de medidas para limitar os incômodos visuais no canteiro.

A limpeza externa era realizada de acordo com a necessidade, já que a localização do empreendimento era pouco populosa. As recomendações sanitárias municipais também foram cumpridas.

Em relação ao critério 3.2.3 - Limitar os incômodos devido à circulação de veículos, a circulação de veículos deve atender as regulamentações locais e os incômodos referente ao fluxo dos trabalhadores e ao estacionamento de funcionários deve ser reduzido.

A movimentação intensa de veículos de funcionários, de visitantes e de fornecedores no empreendimento "A" foi realizada de forma planejada para evitar transtornos para os funcionários e pessoas do entorno. A obra também contou com estacionamento para carros e motos e um bicicletário. 
O critério 3.2.4 - Limitar os incômodos devidos ao material particulado, à lama, aos derramamentos de concreto, garante a limpeza do canteiro e a otimização da limpeza das máquinas e dos utensílios, que vai além da lavagem e manutenção regular.

O empreendimento utilizou telas ao redor do canteiro que barravam parte do material particulado. Um carro pipa também umectava as vias internas e externas para reduzir esses incômodos.

O item 3.3 - Redução da poluição e do consumo de recursos no canteiro de obras, tem início com o critério 3.3.1 - Limitar a poluição da água e do solo, que visa o atendimento aos requisitos regulamentadores para limitar a poluição da água e do solo. Prevê a escolha de produtos que oferecem baixa toxicidade e identificação de produtos potencialmente poluidores, bem como adoção de medidas que protejam as áreas de estocagem desses produtos. E garante a recuperação e tratamento dos efluentes.

Para atender esse critério, foram adotadas uma série de medidas. No canteiro havia várias fossas provisórias, pois as instalações sanitárias ainda não eram ligadas à rede pública. O efluente dessas fossas era coletado por empresas terceirizadas e encaminhado para receber tratamento adequado. Durante a coleta alguns cuidados eram tomados para não haver vazamento e contaminação do solo e da água. Os MTRs de coleta eram arquivados, porém não havia planilha de controle.

No Almoxarifado do empreendimento "A", os produtos químicos eram estocados em um local adequado e ao lado de cada produto havia a FISPQ - Ficha de Informação de Segurança de Produto Químico, onde todas as informações relacionadas a esse produto estavam descritas para ser consultada em caso de vazamento ou de acidente com algum colaborador.

O risco de vazamento em máquinas e equipamentos é frequente, tanto acidental quanto em processo de manutenção. Por isso, os colaboradores eram orientados a comunicar ao setor de Meio Ambiente ou de Segurança do Trabalho em caso de vazamento, mas também sabiam todo o procedimento que deveria ser feito.

O setor de Segurança do Trabalho e de Almoxarifado faziam vistoria antes das máquinas e equipamentos serem utilizadas para avaliar as condições de segurança e uso. Em caso de irregularidade ou risco, os equipamentos e máquinas eram enviados para manutenção.

Mesmo com a manutenção preventiva periódica e as inspeções do setor de Segurança do Trabalho e Almoxarifado, ainda ocorriam vazamentos acidentais. Nesse caso, as máquinas e equipamentos eram mandados para manutenção corretiva. As manutenções eram realizadas com uso de lonas e outros meios para impedir a contaminação do solo e da água.

Quando ocorria algum vazamento acidental, eram tomadas as devidas medidas mitigadoras e também a formalização da ocorrência, através da emissão de uma não conformidade. Para a mitigação era utilizado pó de serra, oriundo das sobras de madeira da carpintaria, no local do vazamento. O uso do pó de serra contém a infiltração no solo e facilita o recolhimento do solo contaminado, evitando o agravamento da contaminação. O solo contaminado é destinado como resíduo perigoso.

O cuidado para evitar e mitigar os vazamentos decorrentes dos efluentes ou das máquinas e equipamentos foi de grande importância para diminuir os riscos de poluição da água e do solo.

No critério 3.3.2 - Limitar a poluição do ar, que visa o atendimento aos requisitos regulamentadores, principalmente relacionados à proibição de queima e às prescrições de segurança indicadas em produtos, e adoção de técnicas construtivas para limitar a poluição do ar e a dispersão de poeiras.

As medidas adotadas para atender essa categoria foram à proibição da queima de qualquer material dentro do canteiro e obras, a umectação de vias, uso de telas de proteção que barravam a poeira e outros materiais particulados, manutenção de máquinas e equipamentos, bem como a medição de fumaça negra através da escala Ringelmann nas máquinas e equipamentos movidos a diesel.

O critério 3.3.3 - Limitar o consumo de recursos, visa o controle e a adoção de medidas para limitar os consumos de água e energia, bem como a redução de retirada de terra do canteiro de obras.

No empreendimento " $\mathrm{A}$ ", era realizado o acompanhamento dos consumos de água e energia através de uma planilha de indicadores de sustentabilidade. Também foram colocadas placas de sensibilização para conscientizar os funcionários a reduzir esses consumos.

Parte do material de escavação das fundações foram reutilizadas como aterro no próprio canteiro, reduzindo a retirada de terra da obra. 
No item 3.4 - Consideração de aspectos sociais no canteiro de obras, o primeiro critério é o 3.4.1 - Limitar riscos sanitários, que prevê a limitação dos riscos sanitários relacionados à contaminação casada pela picada dos insetos causadores da dengue.

Para atender esse critério, eram realizados campanhas, treinamentos e sensibilização através de placas para educar os trabalhadores e conscientizá-los a colaborar com a equipe de Meio Ambiente, monitorando suas frentes de serviço e avisando quando identificassem algum foco de dengue ou qualquer irregularidade que oferecesse riscos sanitários. Além disso, o setor de Meio Ambiente fazia inspeções diárias no canteiro

O critério 3.4.2 - Estimular a formalidade na cadeia produtiva da construção civil, garante a formalidade fiscal e trabalhista de empresas contratadas e/ou subcontratadas, bem como dos demais prestadores de serviço envolvidos nas atividades do canteiro de obras.

Algumas empresas contratadas ou subcontratadas vêm de outro estado ou até mesmo de outros países para prestar serviços e os funcionários necessitam de ambientes para se acomodar. Para atender esse critério, o empreendimento "A" tomou alguns cuidados com relação aos colaboradores das empresas terceirizadas. O setor de Segurança do Trabalho ficou responsável por fiscalizar se as acomodações disponibilizadas pela empresa terceirizada eram adequadas para receber os funcionários.

Outra questão que o setor de Segurança também fiscalizava era se a empresa atendia todos os direitos dos funcionários garantidos pelo Ministério do Trabalho (seja uma empresa local ou não). No caso da alimentação, o setor de Segurança do Trabalho verificava se os funcionários recebiam cesta básica, se as refeições eram adequadas em condições salubres (no caso de se alimentar no refeitório) ou se o valor recebido para alimentação era o suficiente.

O empreendimento "B" teve início em outubro de 2012, sendo inaugurado em outubro de 2014, totalizando, também, um período de 25 meses. Conforme sugerido pelos auditores, o processo de certificação foi implantado ainda na fase de planejamento do empreendimento.

Para atender o critério 3.1.1 - Otimizar a coleta, triagem e o agrupamento dos resíduos do canteiro de obras do item é o 3.1 - Otimização da gestão dos resíduos do canteiro de obras, da Categoria 3, ainda na fase de planejamento, o empreendimento "B", desenvolveu estimativas de geração e valorização de resíduos e elaborou o Plano de Gerenciamento de Resíduos Sólidos - PGRS. Na fase de execução foram criadas centrais de triagem de resíduos que ficavam localizadas no térreo, compostas por caçambas do tipo contêiner, para armazenamento dos resíduos, fornecidas pela própria empresa que realizava a coleta, transporte e destinação final, da mesma forma que ocorreu no empreendimento "A", porém de uma forma mais organizada.

Também foram criadas centrais provisórias localizadas nas lajes, compostas por baias e utilizados caixotes de madeira identificados com as cores previstas pela legislação. Essas baias e caçambas eram sinalizadas com placas com as cores padronizadas, conforme a legislação, que identificavam o tipo de resíduo que deveria ser armazenado em cada caçamba.

Como foi mencionado, o processo de certificação no empreendimento "B" teve início ainda na fase de planejamento, portanto todos os contratos apresentavam uma cláusula referente às exigências da certificação AQUA.

Se tratando de atender o critério 3.1.2 - Beneficiar o máximo possivel os resíduos de canteiro e de forma coerente com as cadeias locais existentes, bem como garantir a correta destinação destes resíduos, foi feita a seleção para escolha da transportadora e da destinação adequada dos resíduos, constatou-se que a cadeia de beneficiamento e valorização de resíduos próxima ao empreendimento "B" é pouco desenvolvida quando comparada a do empreendimento "A".

Diferente do empreendimento "A", que valorizava os resíduos orgânicos e de gesso, o empreendimento "B" não encontrou nenhum receptor que desenvolvesse compostagem ou processamento de gesso. No entanto, enviá-los para um local que houvesse valorização como, por exemplo, para o município do empreendimento "A", seria inviável economicamente. Portanto, não houve valorização desses tipos de resíduos.

O resíduo perigoso no empreendimento "B" gerava energia em seu processo de incineração, portanto houve valorização desse tipo de resíduo. Diferentemente do empreendimento "A", cujo resíduo perigoso era simplesmente incinerado, não havendo valorização.

Entravam no percentual de valorização a madeira, o metal, o papel, o plástico, o entulho e o perigoso. A madeira era enviada para reutilização, o resíduo perigoso gerava energia em sua queima, o metal, o papel, o plástico e o entulho eram encaminhados para usinas de reciclagem, onde eram submetidos a processos de reciclagem compatíveis com cada tipo de material. O resíduo orgânico, o lixo comum e o gesso eram enviados para o aterro sanitário, logo, não eram valorizados. 
Todos os MTRs e medições eram arquivados no final de cada mês. Através dos MTRs, foi desenvolvida uma planilha de controle de resíduos para calcular os quantitativos gerados e sua valorização, a fim de verificar se as metas estavam sendo atingidas.

O critério 3.1.3 - Minimizar a produção de resíduos do canteiro de obras na fonte, prevê a minimização de geração de resíduos através de cláusula contratual, das medidas de gestão e organização do canteiro e dos processos construtivos praticados.

Como foi mencionado anteriormente, o processo de certificação no empreendimento "B" teve início ainda na fase de planejamento, portanto todos os contratos apresentavam uma cláusula referente às exigências da certificação AQUA, inclusive sobre o critério 3.1.3.

O empreendimento "B" também seguiu a ordem de prioridade de não geração, redução, reutilização, reciclagem, tratamento dos resíduos sólidos e disposição final ambientalmente adequada dos rejeitos, contida na Política Nacional dos Resíduos Sólidos - PNRS para atender o critério 3.1.3 como medida de gestão e organização do canteiro.

Para incentivar a não geração, a redução da geração e a reutilização de resíduos, no empreendimento "B" também foram realizados vários treinamentos e campanhas sobre temas referentes aos critérios da Categoria 3 e apresentados cartazes informativos e de sensibilização para os colaboradores.

A escolha dos materiais que são utilizados também foi importante na questão da minimização da geração de resíduos. Para isso, o empreendimento "B" contou com um Sistema de Gestão Integrado - SGI, onde outros setores, como o da qualidade e o de compras, trabalharam junto com o setor de meio ambiente, trazem ganho econômico e ambiental para a construção.

O setor de qualidade verificava o andamento das atividades e a qualidade dos produtos usados, garantindo uma execução correta dos serviços e durabilidade dos materiais, evitando retrabalhos e problemas posteriores, colaborando com a redução da geração de resíduos e no uso de matéria-prima.

O setor de compras, por sua vez, teve importância na relação do custo-benefício, no uso de materiais com grau de toxicidade e na redução do uso de materiais potencialmente poluidores.

O SGI evitou o desperdício de materiais por erros de execução de serviços, retrabalhos e desconstruções no empreendimento "B", reduzindo os custos, o consumo de recursos naturais e a geração de resíduos.

Para atender esse critério, o empreendimento " $\mathrm{B}$ " também usou estruturas pré-moldadas de concreto e metálicas, o que garantiu agilidade ao processo construtivo, mais qualidade e maior longevidade ao empreendimento, além de reduzir a geração de resíduos e proporcionar ao empreendimento "B" um canteiro de obras mais limpo.

Todas essas ações que foram desenvolvidas no empreendimento "B" para atender o item 3.1, que trata da otimização da gestão dos resíduos, servem como base para entender os dados de geração e valorização de resíduos evidenciados na construção desse empreendimento.

Atendendo o critério 3.1.1, foi realizada uma estimativa de geração e valorização de resíduos que estão contidas no Plano de Gerenciamento de Resíduos Sólidos - PGRS.

Para o cálculo da estimativa de geração de resíduos no empreendimento "B" foi considerado o quantitativo de resíduos gerados na construção do empreendimento "A". A diferença de área entre os dois empreendimentos também foi levada em consideração, visto que em um empreendimento menor teoricamente geraria menos resíduos. As semelhanças entre esses empreendimentos lhes atribuíam as mesmas características em termo de quantidades e tipos de resíduos a serem gerados, o que justifica a estimativa do empreendimento "B" ser baseada na geração de resíduos do empreendimento "A".

A valorização de resíduos no empreendimento "B", no entanto, não pode ser baseada nos dados do empreendimento "A", como no caso da estimativa de geração. O fato dos empreendimentos "A" e "B" serem situados em locais distintos, também atribuiu distinção nos tipos de resíduos que poderiam ser valorizados, devido à diferença de empresas transportadoras e receptoras dos resíduos.

A estimativa da geração e valorização de resíduos apresentada no Plano de Gerenciamento de Resíduos Sólidos PGRS pode ser observada na Tab. (05). 
Tabela 05: Estimativa de geração de RCC no empreendimento "B".

\begin{tabular}{c|c|c}
\hline \multicolumn{2}{c}{ ESTIMATIVA DE GERAÇÃO DE RESIDUOS NO EMPREENDIMENTO B } \\
\hline RESÍDUO & PESO DE RCC (KG) & PERCENTUAL DE GERAÇÃO (\%) \\
Madeira & 1.128 .030 & 2,801 \\
Metal & 332.590 & 0,826 \\
Papel/Plástico & 44.100 & 0,109 \\
Lixo Comum & 1.400 .140 & 3,476 \\
Orgânico & 443.440 & 1,101 \\
Entulho & 36.414 .500 & 90,408 \\
Gesso & 228.530 & 0,567 \\
Perigoso & 286.540 & 0,711 \\
Total & 40.277 .870 & 100,00 \\
\hline \multicolumn{2}{|c}{} \\
\hline
\end{tabular}

Fonte: Gomes, 2015.

No empreendimento "A" o gesso e o orgânico eram valorizados, no empreendimento "B" eram destinados para aterro sanitário, portanto não entravam no percentual de valorização. Já o resíduo perigoso era valorizado no empreendimento "B", pois o processo de incineração gerava energia, enquanto no empreendimento "A" não entrava no percentual de valorização, pois era simplesmente incinerado.

O cálculo de estimativa de geração dos resíduos do empreendimento "B" foi feito para alcançar uma redução de, em média, $50 \%$ quando comparado a geração de resíduos no empreendimento " $\mathrm{A}$ ".

Os dados referentes a geração de resíduos foram registrados de janeiro de 2013 a novembro de 2014, totalizando 23 meses. Por mais que a inauguração do empreendimento tendo ocorrido no mês de outubro/2014, a geração perdurou por mais um mês devido à continuidade de algumas atividades.

$\mathrm{Na}$ fase de execução da obra, a geração de resíduos não foi tão intensa quanto no empreendimento "A", como pode ser observado na Tab. (06). Os resíduos no empreendimento "B" não costumavam ficar acumulados, diferentemente do empreendimento "A". Logo, o quantitativo apresentado no mês foi realmente gerado naquele período, o que justifica o equilíbrio na maioria dos meses. Algumas disparidades entre os meses podem ser justificadas pela mudança de atividades.

Não ter ocorrido acúmulo pode ser justificado pelo fato da equipe de Meio Ambiente receber um suporte maior, tanto pelo aumento do efetivo de campo, quanto da equipe técnica. A equipe técnica era mais experiente, pois parte dessa equipe participou da construção do empreendimento "A", o que contribuiu para o desempenho do empreendimento "B".

Tabela 06: Geração de resíduos referente ao ano de 2013 e 2014 no empreendimento "B".

\begin{tabular}{|c|c|c|c|c|c|c|c|c|c|}
\hline MÊS & $\underset{\text { (KG) }}{\text { MADEIRA }}$ & $\underset{(\mathrm{KG})}{\text { METAL }}$ & $\begin{array}{c}\text { PAPEL/ } / \\
\text { PLÁSTICO } \\
\text { (KG) }\end{array}$ & \begin{tabular}{|c|} 
LIXO \\
COMUM \\
(KG)
\end{tabular} & $\underset{\text { (KG) }}{\text { ORGÂNICO }}$ & $\underset{\text { (KG) }}{\text { ENTULHO }}$ & $\begin{array}{c}\text { GESSO } \\
\text { (KG) }\end{array}$ & $\begin{array}{c}\text { PERIGOSO } \\
\text { (KG) }\end{array}$ & $\begin{array}{l}\text { TOTAL } \\
\text { (KG) }\end{array}$ \\
\hline $\mathrm{JAN} / \mathbf{1 3}$ & 23.582 & 4.627 & 1.922 & 13.582 & 38.688 & 447.744 & 0 & 3.575 & 533.719 \\
\hline $\mathrm{FEV} / 13$ & 19.481 & 3.590 & 1.495 & 10.480 & 28.272 & 732.598 & 0 & 10.725 & 806.640 \\
\hline MAR/13 & 18.968 & 0 & 1.332 & 11.235 & 37.914 & 1.953 .283 & 0 & 3.575 & 2.026 .307 \\
\hline$A B R / 13$ & 13.329 & 3.545 & 1.161 & 23.517 & 9.999 & 4.165 .768 & 0 & 3.575 & 4.220.895 \\
\hline $\mathrm{MAI} / 13$ & 2.563 & 4.079 & 1.375 & 14.420 & 8.571 & 159.159 & 0 & 0 & 190.168 \\
\hline $\mathrm{JUN} / 13$ & 12.816 & 5.020 & 1.904 & 22.008 & 9.285 & 615.998 & 0 & 14.300 & 681.331 \\
\hline $\mathrm{JUL} / 13$ & 14.867 & 6.980 & 1.008 & 25.655 & 10.714 & 1.299 .157 & 0 & 14.300 & 1.372 .680 \\
\hline $\mathrm{AGO} / 13$ & 18.968 & 3.140 & 1.002 & 24.859 & 11.785 & 772.358 & 0 & 10.725 & 842.837 \\
\hline $\mathrm{SET} / 13$ & 27.170 & 12.910 & 1.373 & 35.632 & 15.323 & 1.887 .377 & 3.318 & 10.725 & 1.993 .828 \\
\hline $\mathrm{OUT} / 13$ & 37.423 & 11.397 & 1.749 & 56.550 & 17.499 & 1.357 .574 & 3.918 & 7.150 & 1.493 .260 \\
\hline Nov/13 & 57.417 & 12.236 & 1.319 & 75.414 & 16.428 & 1.937 .892 & 1.959 & 14.300 & 2.116 .965 \\
\hline $\mathrm{DEZ} / 13$ & 28.708 & 7.686 & 1.348 & 58.101 & 13.679 & 3.871 .237 & 0 & 7.150 & 3.987 .909 \\
\hline $\mathrm{JAN} / 14$ & 43.063 & 17.759 & 1.574 & 113.226 & 18.213 & 3.309 .108 & 24.038 & 21.450 & 3.548 .431 \\
\hline $\mathrm{FEV} / 14$ & 47.169 & 3.800 & 1.323 & 128.904 & 18.570 & 2.329 .668 & 0 & 21.450 & 2.550 .884 \\
\hline $\mathrm{MAR} / 14$ & 45.113 & 14.490 & 1.516 & 108.543 & 14.018 & 1.665 .048 & 10.360 & 17.875 & 1.876 .962 \\
\hline$A B R / 14$ & 65.619 & 16.200 & 2.723 & 79.941 & 16.566 & 1.007 .424 & 15.540 & 25.025 & 1.229 .039 \\
\hline $\mathrm{MAI} / 14$ & 94.328 & 49.063 & 1.956 & 88.545 & 17.142 & 3.735 .864 & 36.260 & 7.150 & 4.030.307 \\
\hline $\mathrm{JUN} / 14$ & 86.125 & 14.870 & 3.005 & 73.989 & 12.142 & 804.540 & 25.900 & 17.875 & 1.038 .446 \\
\hline $\mathrm{JUL} / 14$ & 133.289 & 54.971 & 5.090 & 108.405 & 17.261 & 1.315 .248 & 41.440 & 17.875 & 1.693 .578 \\
\hline $\mathrm{AGO} / 14$ & 145.592 & 34.947 & 516 & 113.980 & 18.570 & 932.917 & 54.908 & 10.725 & 1.312 .155 \\
\hline $\mathrm{SET} / 14$ & 183.529 & 27.773 & 3.036 & 305.533 & 23.927 & 797.544 & 40.148 & 17.875 & 1.399 .364 \\
\hline OUT/14 & 239.920 & 1.500 & 55.969 & $\begin{array}{l}1.180 .010 \\
\end{array}$ & 18.213 & 566.676 & $\begin{array}{l}70.875 \\
62.875\end{array}$ & 14.300 & 2.139.464 \\
\hline NOV/14 & 8.802 & 0 & 0 & 304.824 & 4.643 & 20.988 & 0 & 14.300 & 353.557 \\
\hline
\end{tabular}

Fonte: Gomes, 2015. 
No ano de inauguração, houve chegada dos lojistas que são pessoas responsáveis pelas obras de cada loja, chegada também dos funcionários responsáveis pela operação do shopping e início do abastecimento das lojas, o que gera grande quantidade de resíduos oriundos das embalagens que trazem os produtos. No entanto, essa geração não se excedeu com o ritmo acelerado da obra, permaneceu constante nos dois anos. O total de resíduos gerados entre janeiro de 2013 e novembro de 2014 foi de $41.438 .728 \mathrm{~kg}$, ou seja, $134,81 \mathrm{~kg} / \mathrm{m}^{2}$. Uma geração bem inferior comparada ao empreendimento "A". Na Figura 04, a seguir, é possível verificar um comparativo entre a geração de resíduos nos dois empreendimentos.

Figura 04: Gráfico comparativo da geração de resíduos entre os empreendimentos "A" e "B".

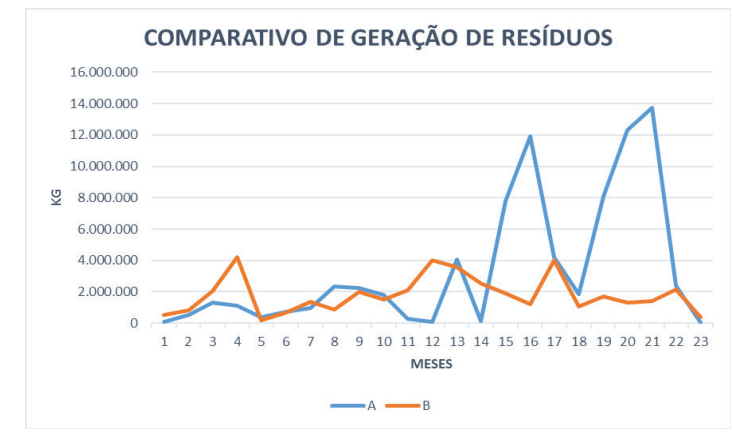

Fonte: Gomes, 2015.

O empreendimento "B" também obteve um bom percentual de valorização na maioria dos meses, porém, novamente, o percentual teve uma redução no mês de inauguração, pois o quantitativo de funcionários aumenta nesse período, tanto para atender o ritmo acelerado da obra e também para trabalhar na operação do shopping, e conscientizar todas essas pessoas é um trabalho que exige tempo para ministrar treinamentos e campanhas.

Mesmo havendo redução da valorização, o índice não reduziu tanto como no empreendimento "A", chegou a 41,05\% e voltou a atingir bom nível em novembro, 95,6\%, como pode ser observado no Fig. 05.

Figura 05: Gráfico comparativo de valorização de resíduos entre os empreendimentos “A" e "B".

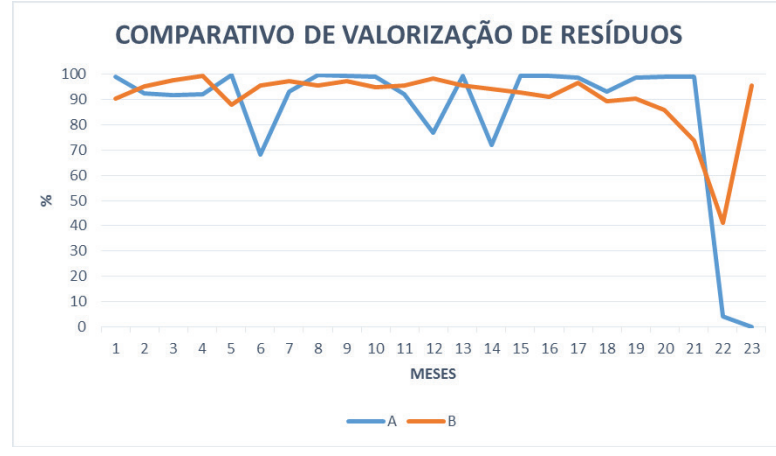

Fonte: Gomes, 2015.

A Tabela 07, a seguir, apresenta os percentuais de valorização referentes aos anos de 2013 e 2014, do empreendimento "B". 
Tabela 07: Percentual de valorização de resíduos referente a 2013 e 2014 no empreendimento "B”.

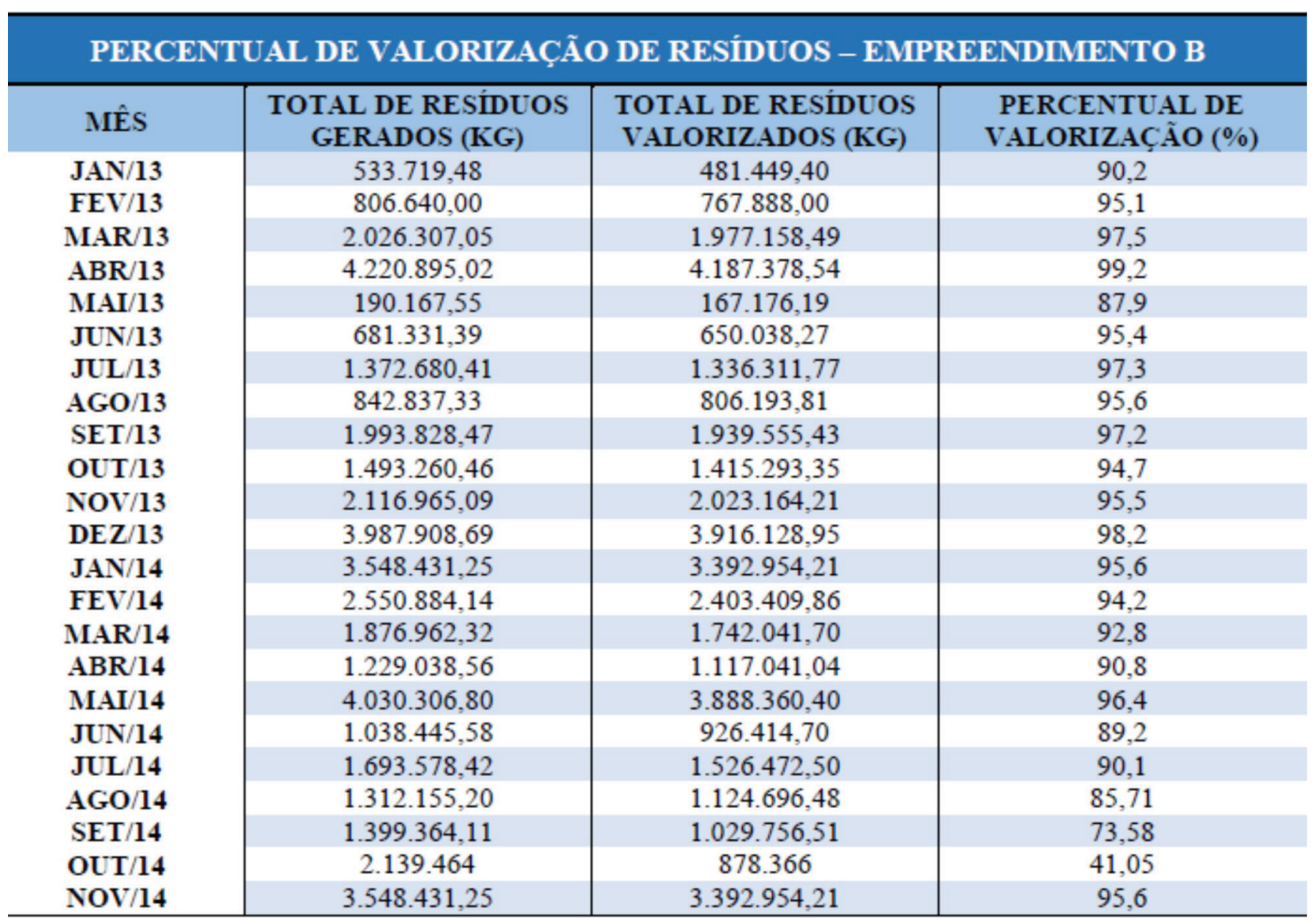

Fonte: Gomes, 2015.

No item 3.2 - Redução dos incômodos causados pelo canteiro de obras, o primeiro critério de avaliação é o 3.2 .1 Limitar os incômodos sonoros, que exige a identificação e caracterização das origens dos ruídos, bem como a elaboração de estratégias para a redução desses incômodos sonoros e a garantia do respeito ao nível de ruído máximo permitido ao entorno do canteiro. Também prevê a realização de estudo de acústica, a adoção de técnicas construtivas minimizadoras dos incômodos sonoros e o uso de materiais e máquinas em conformidade com a regulamentação, com as orientações dos fabricantes e em boas condições.

O empreendimento "B" realizou a medição de ruído em algumas etapas da obra para avaliar se os ruídos do canteiro de obra estavam dentro do limite permitido pelas normas, para não prejudicar os funcionários e a circunvizinhança e, assim, atender as exigências desse critério.

As máquinas e equipamentos passavam por manutenções para que não emitissem ruídos capazes de prejudicar os funcionários. Também as atividades que emitissem ruído significativo eram controladas através dos horários de funcionamento.

Assim como o empreendimento "A", o empreendimento "B" também disponibilizou para a circunvizinhança um telefone para contato com o setor social, cujo recebe formalmente a reclamação e a repassa para o setor responsável pela solução do problema.

O critério 3.2.2 - Limitar os incômodos visuais, exige que seja feita a limpeza semanal do canteiro e de suas periferias. Também devem ser cumpridas as recomendações sanitárias municipais, bem como a adoção de medidas para limitar os incômodos visuais no canteiro.

Esse critério exigiu mais cuidado no empreendimento "B" do que no empreendimento "A". Por se tratar de uma região mais populosa, a limpeza externa no empreendimento " $\mathrm{B}$ " era realizada frequentemente. Uma vez por semana ou de acordo com a necessidade.

Em relação ao critério 3.2.3 - Limitar os incômodos devido à circulação de veículos, a circulação de veículos deve atender as regulamentações locais e os incômodos referente ao fluxo dos trabalhadores e ao estacionamento de funcionários deve ser reduzido. 
Atendendo a esse critério, o empreendimento "B" criou várias portarias para facilitar o acesso e movimentação de veículos de funcionários, de visitantes e de fornecedores. Também criou o bicicletário e o estacionamento para carros e motos. Toda a estrutura foi montada de forma planejada para evitar transtornos para os funcionários e pessoas do entorno. Todos os acessos eram bem sinalizados para evitar transtornos.

O critério 3.2.4 - Limitar os incômodos devidos ao material particulado, à lama, aos derramamentos de concreto, garante a limpeza do canteiro e a otimização da limpeza das máquinas e dos utensílios, que vai além da lavagem e manutenção regular.

O empreendimento utilizou telas ao redor do canteiro que evitavam que o material particulado atingisse a área externa. Um carro pipa também umectava as vias internas e externas para reduzir esses incômodos pela dispersão de poeira no canteiro. $\mathrm{Na}$ área externa circulava um equipamento chamado varredeira que realizava a limpeza das ruas. $\mathrm{Na}$ área interna a mini varredeira também realizava a limpeza das lajes.

O empreendimento "B" implantou o lava-rodas, espaço para lavagem dos pneus dos carros antes de saírem do canteiro, a fim de evitar que a lama gerada na parte interna fosse levada para a parte externa.

Outro destaque para o empreendimento "B" foi a aquisição da Recicladora de Concreto, uma máquina instalada dentro do próprio canteiro para processar as sobras de concreto e gerar um material chamado solo-brita (muito parecido com Brita Graduada Simples - BGS) que era reutilizado no canteiro de obras.

Essas tecnologias, lava-rodas e recicladora de concreto, não existiam no empreendimento " $\mathrm{A}$ ".

O item 3.3 - Redução da poluição e do consumo de recursos no canteiro de obras, tem início com o critério 3.3.1 - Limitar a poluição da água e do solo, que visa o atendimento aos requisitos regulamentadores para limitar a poluição da água e do solo.

Enquanto as instalações não eram ligadas à rede pública, no canteiro de obras eram usadas fossa sépticas para armazenar o efluente gerado, cujo era coletado por uma empresa terceirizada, contratada para realizar o transporte, a destinação e o tratamento adequados. Durante a coleta alguns cuidados eram tomados para não haver vazamento e contaminação do solo e da água. Os MTRs de coleta eram guardados e controlados através de uma planilha.

O Almoxarifado estocava os produtos químicos em local adequado. Ao lado de cada produto havia a FISPQ Ficha de Informação de Segurança de Produto Químico, onde todas as informações relacionadas a esse produto estavam descritas para ser consultada em caso de vazamento ou de acidente envolvendo um funcionário.

Assim como no empreendimento " $\mathrm{A}$ " antes de serem utilizadas, todas as máquinas e equipamentos eram vistoriadas pelos setores de Segurança do Trabalho e do Almoxarifado para avaliar as condições de segurança e uso. Quando apresentavam irregularidade ou risco, os equipamentos e máquinas eram enviados para manutenção.

Mesmo com a manutenção preventiva periódica e as inspeções, ainda ocorriam vazamentos acidentais, bem comuns em máquinas e equipamentos de obras. Nesse caso, as máquinas e equipamentos eram mandados para manutenção corretiva, que eram realizadas com uso de lonas e outros meios para impedir a contaminação do solo e da água.

Quando ocorria algum vazamento acidental, eram tomadas as devidas medidas mitigadoras e também a formalização da ocorrência, através da emissão de uma não conformidade. Para a mitigação era utilizado pó de serra, oriundo das sobras de madeira da carpintaria, no local do vazamento. $\mathrm{O}$ uso do pó de serra contém a infiltração no solo e facilita o recolhimento do solo contaminado, evitando o agravamento da contaminação. O solo contaminado é destinado como resíduo perigoso.

Os cuidados tomados, no empreendimento "B", para evitar e mitigar os vazamentos decorrentes dos efluentes ou das máquinas e equipamentos foi de grande importância para diminuir os riscos de poluição da água e do solo.

No critério 3.3.2 - Limitar a poluição do ar, que visa o atendimento aos requisitos regulamentadores, principalmente relacionados a proibição de queima e às prescrições de segurança indicadas em produtos, e adoção de técnicas construtivas para limitar a poluição do ar e a dispersão de poeiras. As medidas adotadas para atender essa categoria foram a proibição da queima de qualquer material dentro do canteiro e obras, a umectação de vias, uso de telas de proteção que barravam materiais particulados (poeira), manutenção de máquinas e equipamentos, bem como a medição de fumaça negra através da escala Ringelmann.

No critério 3.3.3 - Limitar o consumo de recursos, visa o controle e a adoção de medidas para limitar os consumos de água e energia, bem como a redução de retirada de terra do canteiro de obras. 
Atendendo esse critério, o empreendimento "B" realizava o acompanhamento dos consumos de água e energia através de uma planilha de indicadores de sustentabilidade. Também foram colocadas placas de sensibilização e realizados treinamentos para conscientizar os funcionários a reduzir esses consumos. No lava-rodas a água era reutilizada para a lavagem dos pneus através de um sistema conjunto de decantação e bombeamento, onde a água lavava os pneus dos veículos e em seguida escoava para um tanque de decantação, em que a água, livre de sedimentos, era bombeada para uma caixa d'água e novamente reutilizada para lavar outros carros.

Na recicladora de concreto (Fig. 06) o sistema era semelhante. A água resultante das lavagens dos caminhões passava por três tanques de decantação e, livre dos sedimentos, era bombeada diretamente para a recicladora. No processamento do concreto, a água era retirada da recicladora e retornava para o último decantador através de uma calha e o material produzido pela recicladora era seco, chamado de solo-brita.

O solo-brita (Fig. 07), produzido pela recicladora, é um material muito parecido com o BGS. Dessa forma, o consumo de BGS era evitado na obra através da substituição pelo solo-brita.

Parte do material de escavação das fundações foram reutilizadas como aterro no próprio canteiro, reduzindo a retirada de terra da obra.

Figura 06: Reuso da água na recicladora de concreto.

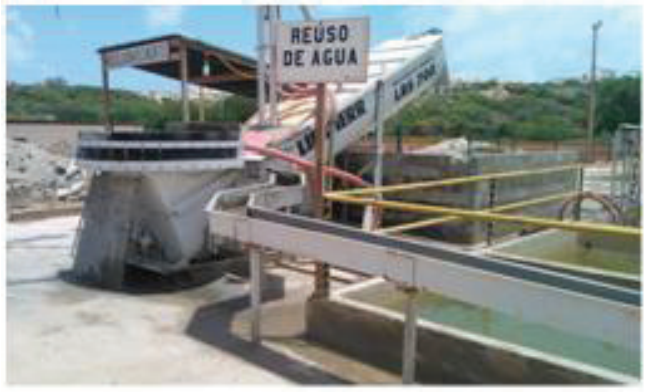

Fonte: Gomes, 2015.
Figura 07: Solo brita reutilizado.

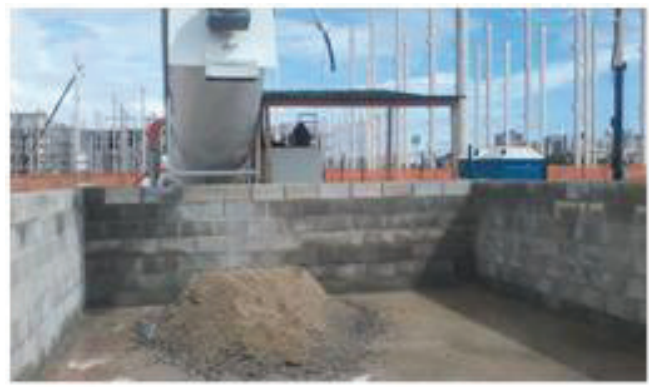

Fonte: Gomes, 2015.

Outra forma de minimizar o consumo de recursos foi a criação da Central de Triagem de Madeira. Essa central foi um espaço desenvolvido para separar e armazenar as madeiras que retornavam do campo, mas que ainda estavam em bom estado de uso. Posteriormente, essa madeira retornava para ser reutilizada em outras atividades no canteiro.

Como medida compensatória para a supressão da vegetação no canteiro do empreendimento "B", foram plantadas várias mudas no entrono. Parte dessa madeira foi reutilizada para confecção de gradis para essas mudas. Outra parte foi reutilizada na confecção de guarda corpos.

No item 3.4 - Consideração de aspectos sociais no canteiro de obras, o primeiro critério é o 3.4.1 - Limitar riscos sanitários, que prevê a limitação dos riscos sanitários relacionados à contaminação casada pela picada dos insetos causadores da dengue.

Para atender esse critério, eram realizados campanhas, treinamentos e sensibilização através de placas para educar os trabalhadores e conscientizá-los a colaborar com a equipe de Meio Ambiente, monitorando suas frentes de serviço e avisando quando identificassem algum foco de dengue ou qualquer irregularidade que oferecesse riscos sanitários. Também foi montada uma equipe interna, treinada pelos próprios agentes sanitários da prefeitura, que vistoriavam frequentemente o canteiro.

O critério 3.4.2 - Estimular a formalidade na cadeia produtiva da construção civil, garante a formalidade fiscal e trabalhista de empresas contratadas e/ou subcontratadas, bem como dos demais prestadores de serviço envolvidos nas atividades do canteiro de obras.

Para atender esse critério, o empreendimento "B" responsabilizou o setor de Segurança do Trabalho para garantir os direitos trabalhistas dos funcionários de empresas contratadas ou subcontratadas que vinham de outras regiões para prestar serviços e se acomodavam em residências locais. Para isso, o setor de Segurança do Trabalho fiscalizava se as acomodações disponibilizadas pela empresa terceirizada eram adequadas para receber os funcionários. 
Outra questão que o setor de Segurança também fiscalizava era se a alimentação fornecida pelas empresas atendia as condições de salubridade, se as refeições eram adequadas (no caso de se alimentar em refeitório) ou se o valor recebido para alimentação era o suficiente e ainda se os funcionários estavam recebendo cesta básica.

Cada empreendimento desenvolveu ações para atender os critérios da Categoria 3 e reduzir os impactos ambientais decorrentes das atividades das construtoras. Essas ações estão contidas no Sistema de Gestão Ambiental desenvolvido e implantado em cada empreendimento com o objetivo de obter o Selo AQUA - Alta Qualidade Ambiental.

Dentre os dois empreendimentos escolhidos para o estudo de caso, o primeiro buscou o processo de certificação durante a fase de execução e o segundo deu início ao processo ainda na fase de planejamento.

Neste tópico será analisado o desempenho ambiental dos empreendimentos, considerando os níveis da certificação em cada fase validada (Programa e Concepção) e auditada (Realização). Também será analisada a efetividade da aplicação do Sistema de Gestão Ambiental (SGA) implantado, considerando a fase do empreendimento (planejamento ou execução), em que foi iniciado o processo de certificação.

Mesmo com o início tardio do processo de certificação, o empreendimento "A" ainda conseguiu nível máximo, excelente, na avaliação da Categoria 3 - Canteiro de obras com baixo impacto ambiental, nas fases Programa e Concepção.

$\mathrm{Na}$ fase Programa é elaborado um documento contendo toda a programação necessária para que os projetistas possam realizar a concepção arquitetônica e técnica para que o empreendimento atenda as exigências da certificação. Como o projeto do shopping já estava pronto, inclusive sendo executado, os documentos e informações necessários para essa fase foram elaborados a partir do projeto, seguindo a ordem inversa do procedimento correto. E assim a certificação para essa fase foi alcançada.

A Categoria 3, na fase Programa, é apenas validada e recebeu nível excelente. Nessa fase, foi apresentado o Plano de Gerenciamento de Resíduos Sólidos - PGRS, contendo as estimativas de geração e valorização de resíduos. Nesse período ainda não havia equipe formalizada responsável por esses dados, por isso não foram arquivados e não será possível apresentá-los.

Na fase Concepção os projetistas desenvolvem o projeto arquitetônico e técnico do empreendimento, com base nos documentos elaborados na fase Programa. Como o projeto do shopping conseguiu satisfazer os critérios de avaliação, mesmo estando pronto antecipadamente e já estar sendo executado, o empreendimento recebeu a certificação.

$\mathrm{Na}$ fase Concepção, a Categoria 3 também é apenas validada e novamente foi avaliada com nível excelente. Nessa fase foram revisados os dados mostrados na fase Programa e verificado o andamento dessas questões. Como esse foi o primeiro empreendimento no ramo de shopping centers no Brasil a passar por esse tipo de certificação e também foi a construção piloto em que a construtora atuou sozinha, não havia um modelo a ser seguido e nem outra construção suficientemente sustentável a ponto de servir como base para os cálculos das estimativas. Logo, nesta fase, foi somente analisado em qual nível as exigências do Referencial da Qualidade Ambiental estavam sendo atendidas, concluindo-se que o empreendimento cumpriu as exigências excelentes da Categoria 3.

$\mathrm{Na}$ fase Realização é avaliado se a execução está sendo realizada tal qual como consta no projeto ou nas informações apresentadas anteriormente. Nessa fase, a Categoria 3 é, de fato, auditada. Como foi detalhado no tópico 5.2.1, o empreendimento "A" desenvolveu várias ações para atender as exigências dessa categoria.

Todas essas ações foram avaliadas, segundo o Referencial Teórico do Selo AQUA para Eco construção, Categoria 3 - Canteiro de obras com baixo impacto, apresentada anteriormente. No entanto, só foi possível obter a certificação, para tal categoria, no nível bom, justificado principalmente pela grande geração de resíduos e baixa valorização nos meses finais.

Como a auditoria ocorreu em setembro de 2012, não foi possível visualizar a geração e valorização dos meses de outubro e novembro. Justificar a queda de nível pela geração exorbitante de resíduo é possível, pois os valores de 2012 comprovam esse fato. No entanto, a justificativa pela queda da valorização só é possível pela visita em campo, onde os auditores puderam ver a dificuldade de segregação dos resíduos no próprio canteiro que já estava ocorrendo nessa época.

O empreendimento "A", que só deu início ao processo de certificação a partir da execução, teve maior dificuldade para implantar o seu SGA. Os funcionários atribuíram essas dificuldades ao efetivo reduzido e a falta de apoio da alta direção. Poucos no empreendimento "A" tinham noção do grande impacto que essa construção iria causar.

O seu baixo desempenho obtido através das ações desenvolvidas para a Categoria 3, principalmente se tratando da geração exorbitante dos resíduos, também pode ser atribuído à falta de colaboração dos funcionários, que já tinham 
Sistema de Gestão Ambiental (SGA) e aplicabilidade do Selo AQUA: estudos de casos em empresas construtoras de shopping centers

desenvolvido hábitos não sustentáveis no início da execução e estavam mais resistentes a sensibilização oferecida nos treinamentos.

Todos esses fatos apontam as desvantagens da aplicação do Sistema de Gestão Ambiental apenas a partir da fase de execução.

Diante deste contexto, notou-se a necessidade do desenvolvimento desse sistema, ainda na fase de planejamento no empreendimento "B", assim como a criação de novos setores e implantação do Sistema de Gestão Integrada - SGI para auxiliar no desenvolvimento de todas as atividades, a aquisição de máquinas para dar suporte na gestão de resíduos, a importância de espaços para armazenar resíduos com potencial de reutilização no próprio canteiro de obras, dentre outros investimentos.

Já o empreendimento "B", o processo de certificação teve início ainda no ano de 2012. E a primeira auditoria, referente à fase Programa, foi realizada em fevereiro de 2013. Em novembro do mesmo ano, ocorreu a fase de Concepção, finalizando com a auditoria da fase Realização, em setembro de 2014.

Nesse empreendimento, o nível excelente foi alcançado em todas as fases (Programa, Concepção e Realização) na avaliação da Categoria 3 - Canteiro de obras com baixo impacto ambiental.

Como já mencionado, na fase Programa é elaborado um documento contendo soluções arquitetônicas e técnicas para que o empreendimento atenda às exigências da certificação. Os documentos e informações necessários para essa fase foram elaborados e apresentados na auditoria, garantindo a certificação na fase Programa.

Como informado no tópico anterior a Categoria 3, na fase Programa, é apenas validada e recebeu nível excelente. Nessa fase, foi apresentado o Plano de Gerenciamento de Resíduos Sólidos - PGRS, contendo as estimativas de geração e valorização de resíduos, baseadas na geração do empreendimento " $A$ " e na cadeia de beneficiamento disponível na cidade em que o empreendimento "B" foi implantado.

O cálculo de estimativa de valorização de resíduos foi de 94,97\% de uma estimativa de geração de $40.277 .870 \mathrm{Kg}$. Esse cálculo já previa uma redução de quase 50\%, comparado com a geração de resíduos do empreendimento "A".

$\mathrm{Na}$ fase Concepção os projetistas desenvolvem o projeto arquitetônico e técnico do empreendimento, com base nos documentos elaborados na fase Programa. Como o projeto do shopping foi desenvolvido para satisfazer os critérios de avaliação, e assim, o empreendimento foi certificado para essa fase. Na fase Concepção, a Categoria 3 também é apenas validada e novamente foi avaliada com nível excelente. Nessa fase foram revisados os dados apresentados na fase Programa e verificado o andamento dessas questões. Como essa auditoria foi realizada em novembro de 2013, foram considerados os dados de geração de resíduos até outubro desse mesmo ano. Foi totalizado 14.161.667,16 kg referentes aos 10 meses de construção, representando $35,15 \%$ da geração total em relação a estimativa que foi de 40.277 .870 , concedendo ainda uma margem de 64,85\% de geração de resíduos para os posteriores 13 meses restantes para finalização do empreendimento.

Essa análise, que foi feita apenas para o tópico 3.1, cujo trata da gestão de resíduos, juntamente com a avaliação de outras instalações e medidas, que não existiram no empreendimento " $\mathrm{A}$ ", mas foram aplicadas no empreendimento "B" para atender os outros critérios, resultaram na certificação com nível excelente para essa categoria.

Na fase Realização é avaliado se a execução está sendo realizada tal qual como consta no projeto ou nas informações apresentadas anteriormente.

Nessa fase, a Categoria 3 é, de fato, auditada. Como foi detalhado no tópico 2.5.2, o empreendimento "B" desenvolveu as mesmas ações que o empreendimento "A" e mais algumas, para atender às exigências dessa categoria.

Todas essas ações foram avaliadas, inclusive a geração e valorização dos resíduos, segundo o Referencial Teórico do Selo AQUA para Eco construção, Categoria 3 - Canteiro de obras com baixo impacto. $\mathrm{O}$ alto percentual de valorização no decorrer da obra e a geração de resíduos mais equilibrada, seguindo a política dos 3R's, onde o principal objetivo é reduzir a geração para depois buscar a reutilização seguida da reciclagem, contribuíram bastante para obter a certificação, para tal categoria, no nível excelente.

O empreendimento "A" não teve o suporte necessário para atender com mais eficiência às ações que foram desenvolvidas. Por ser uma obra piloto da construtora, também não teve valores para servir de parâmetros na geração de resíduos. A falta de investimentos como maior número de colaboradores, aquisição de máquinas e equipamentos, limitou o desempenho do empreendimento "A". A resistência aos treinamentos por parte dos colaboradores, já acostumados com a rotina de atividades não sustentáveis antes do processo de certificação, evitou que o empreendimento atingisse melhores resultados. Tudo isso contribuiu para a queda no desempenho desse empreendimento. 
A experiência da construtora no empreendimento "A" fez com que algumas mudanças ocorressem no segundo, contribuindo para melhores resultados. Foi o caso da implementação do setor de Qualidade e do Sistema de Gestão Integrada - SGI, de uma maior estruturação do setor de Meio Ambiente, da aquisição de máquinas e equipamentos, do maior efetivo e do suporte de locais para as práticas de reuso e reutilização dos recursos.

Notou-se que a aplicabilidade de sistemas de gestão ambiental, principalmente na fase de planejamento, em empresas construtoras de grandes empreendimentos é uma ferramenta indispensável para gerenciar suas ações sobre os aspectos ambientais identificados, apresentando-se ainda como oportunidade de mercado, elemento obrigatório nas agendas administrativa e operacional, promovendo a longevidade e sucesso da empresa.

\section{Conclusão}

Com todos os dados apresentados é possível verificar a efetividade da aplicação do Sistema de Gestão Ambiental para a obtenção da certificação AQUA e, principalmente, a efetividade do desenvolvimento desse sistema ainda na fase de planejamento.

Também foi possível analisar o desempenho ambiental considerando os níveis em cada fase da Certificação AQUA para a Categoria 3, observando as diferenças dos níveis alcançados para cada fase em cada empreendimento. Observouse a criação de um novo setor no segundo empreendimento, aquisição de máquinas e equipamentos que auxiliaram no desenvolvimento dos critérios exigidos pela certificação, isso pode ser justificado pelo fato da alta direção ter notado as vantagens que o SGA pode trazer para o empreendimento, caso a equipe responsável possua ferramentas de trabalho adequadas.

Verificou-se que o empreendimento "B", que deu início ao processo de certificação a partir da fase de planejamento, obteve melhores resultados em relação ao empreendimento "A", isso pode ser justificado pelo tempo hábil que esse empreendimento teve para desenvolver os critérios exigidos para a Categoria 3, já que seguiram as orientações dos auditores e consultores e iniciaram o processo a partir da fase indicada.

Em relação ao comparativo da geração de resíduos foi observada uma geração significativamente maior no empreendimento "A", quase o dobro que o empreendimento "B", fortalecendo mais uma vez a desvantagem da aplicação do SGA apenas a partir da fase de execução.

Pode ser constatado que ainda há uma grande resistência em profissionais da área da construção civil, desde o colaborador ao diretor da obra, a respeito de práticas sustentáveis no canteiro. A falta de suporte às práticas das ações que foram desenvolvidas no empreendimento "A", comprovam que as certificações ainda são reconhecidas muitas vezes apenas como marketing e não pelos benefícios ambientais, econômicos e sociais que proporcionam.

A implantação do Sistema de Gestão Integrada - SGI entre os setores, o suporte através de efetivo, máquinas e equipamentos e as práticas de reuso e reutilização dos recursos no canteiro de obras adotados para o empreendimento "B", provam que o investimento é a chave para alcançar um bom desempenho ambiental. E todo esse investimento retorna para a empresa através da redução do consumo de recursos, redução da geração de resíduos, além de proporcionar melhorias ambientais e sociais.

\section{Referências}

ALTA qualidade ambiental - AQUA. Disponível em: <http://www.vanzolini.org.br/conteudo.asp?cod_site=104\&id_ menu $=758>$. Acesso em: 23 out. 2015.

BARBIERI, J. C. Gestão ambiental empresarial: conceitos, modelos e instrumentos. 2. ed. São Paulo: Saraiva, 2007. $382 \mathrm{p}$.

BRASIL. Lei n ${ }^{\circ}$ 12.305, de 02 de agosto de 2010. Institui a Política Nacional de Resíduos Sólidos; altera a Lei no 9.605, de 12 de fevereiro de 1998; e dá outras providências. Diário Oficial da União, Brasília, DF, 3 ago. 2010. Disponível em: <http://www.planalto.gov.br/ccivil_03/_ato2007-2010/2010/lei/112305.h tm>. Acesso em: 4 ago. 2015.

DEGANI, C. M. Sistema de gestão ambiental em empresas construtoras de edifícios. 2003. 263 f. Dissertação (Mestrado) - Curso de Engenharia Civil, Escola Politécnica, Universidade de São Paulo, São Paulo, 2003.

DEGANI, C. M.; CARDOSO, F. C. A Sustentabilidade ao longo do ciclo de vida de edifícios: a importância da etapa de projeto arquitetônico. In: NUTAU SUSTENTABILIDADE, ARQUITETURA E PROJETO URBANO, 2002, São 
Sistema de Gestão Ambiental (SGA) e aplicabilidade do Selo AQUA: estudos de casos em empresas construtoras de shopping centers

Paulo. Anais...São Paulo: FAU - USP, 2002. 1 CD-ROM.

GOMES, G. A. Sistema de Gestão Ambiental (SGA) e aplicabilidade do Selo AQUA: estudos de casos em empresas construtoras de shopping centers. Trabalho de Conclusão de Curso. 2015. 108f. (Graduação em Engenharia Ambiental e Sanitária) - Universidade de Fortaleza, Fortaleza, 2015.

GUPTA, M. C. Environmental Management and its impact on the operations function. International Journal of Operations \& Production Management. Louisville, v. 15, p. 34- 51, oct. 1994.

JOHN, V. M. A construção e o meio ambiente: texto técnico. São Paulo: PCC/EPUST. Disponível em:<www. reciclagem.pcc.usp.br>. Acesso em: 5 set. 2015.

MANO, C. A escolha das melhores. Guia Exame de Sustentabilidade. São Paulo, n. 9, p. 16-18, out. 2008.

PALIARI, J.C. Metodologia para a coleta e análise de informações sobre consumos e perdas de materiais e componentes nos canteiros de obras de edificios. São Paulo, 1999. 473 f. Dissertação (Mestrado) - Escola Politécnica da Universidade de São Paulo, São Paulo, 1999.

PANORAMA dos resíduos sólidos no Brasil 2014. São Paulo: ABRELPE, 2014. 118 p. Disponível em: <http://www. abrelpe.org.br/Panorama/panorama2014.pdf >. Acesso em: 23 ago. 2015.

PORTER, M. E.; LINDE, C. Green and competitive: ending the stalemate. Harvard Bussines Review, Boston, v. 73, n. 5, p. 120-134, sep./oct., 1995.

REFERENCIAL da qualidade ambiental do edifício: comércio - categoria 3: referencial técnico da certificação "Edifícios do setor de serviços - Processo AQUA". Versão 1. São Paulo: Fundação Vanzolini, 2010.

SALAZAR FILHO, H. O. A aplicação da metodologia de produção mais limpa através dos círculos de controle de qualidade - CCQ em uma indústria do setor metal mecânico - estudo de caso. 2002. 120f. Dissertação (Mestrado em Engenharia de Produção) - Universidade Federal de Santa Catarina, Florianópolis, 2002.

SHRIVASTAVA, P. Environmental technologies and competitive advantage. Strategic Management Journal. Chichester, v. 16, p.183-200, 1995. Special issue

SJOSTROM, C. Durability of building materials and componentes. In: CIB SYMPOSIUM ON CONSTRUCTION \& ENVIRONMENT: FROM THEORY INTO PRACTICE 2000, São Paulo. Anais... from theory into practice. São Paulo: CIB PCC USP, 2000. 1 CD-ROM.

TACHIZAWA, T. Gestão ambiental e responsabilidade social corporativa: estratégias de negócios focadas na realidade brasileira. São Paulo: Atlas, 2002.

THORMARK, C. Conservation of energy and natural resources by recycling building waste. Resources, Conservation \& Recycling. n. 33, p. 113-130, 2001.

WILNER, A. Projetos analisados sob Princípios do Equador são minoria. Valor Econômico, 2006. Disponível em:< http://www.valor.com.br>. Acesso em: 13 ago. 2015.

YIN, R. K. Estudo de caso: planejamento e métodos. 5. ed. Porto Alegre: Bookman, 2015. 320 p. Disponível em: $<$ https://books.google.com.br/books?hl=pt-BR\&lr;=\&id=EtOyBQAAQBAJ\&oi=fnd\&pg=PR1\&dq=estudo+de+caso\& ots $=\mathrm{j} 6$ nlny2tz\&sig=DdkO7-h9whBaqfpsGIE-UUz7dXc\#v=onepage \&q=estudo e caso\&f=false $>$. Acesso em: 15 ago. 2015. 
Sobre os autores

\section{Andressa Guimarães Gomes}

Engenheira Ambiental e Sanitarista pela Universidade de Fortaleza (2015). Tem experiência na área de Engenharia Ambiental com ênfase em análises físico-químicas de água e sedimentos, monitoramento ambiental em lagoas costeiras e rios urbanos e implantação e monitoramento de Sistemas de Gestão Ambiental.

\section{Suellen Galvão Moraes}

Especialista em Gestão Ambiental pela Universidade de Fortaleza (2009). Bacharel em Turismo pela Faculdade Integrada do Ceará - FIC (2006). Graduanda em Engenharia Ambiental e Sanitária e monitora da disciplina de Ecossistemas Marinhos e Ambientes Costeiros, Universidade de Fortaleza. Docente e orientadora de Estágio Supervisionado do Curso Técnico de Hospedagem na Escola Profissionalizante do Estado Marly Ferreira Martins e consultora em Gestão Ambiental.

\section{Márcia Thelma Rios Donato Marino}

Possui Graduação em Geologia pela Universidade de Fortaleza (1984), Especialização em Aperfeiçoamento em Mapeamento Geológico pela Universidade Federal de Minas Gerais (1985), Mestrado e Doutorado em Geologia pela Universidade Federal do Ceará (2004 e 2014). Coordenadora do curso de Especialização em Gestão Ambiental da UNIFOR. Professora Adjunta, Nível-1, Universidade de Fortaleza, curso de Graduação em Engenharia Ambiental e Sanitária. Consultora Ambiental cadastrada no IBAMA. Membro da Rede BRASPOR de pesquisadores. Membro do Comitê de Ética da Universidade de Fortaleza.

\section{Denise Fernandes}

Possui graduação em Geologia pela Universidade de Fortaleza (1984), Graduação em Química - Licenciatura, pela Universidade Estadual do Ceará (2002), Mestrado em Geologia pela Universidade Federal do Ceará (2004) e Doutora em Geologia, área Geologia Ambiental, Universidade Federal do Ceará (2015). É professora Assistente 1, da Universidade de Fortaleza, curso de Engenharia Ambiental e Sanitária. Foi assessora de Coordenação do Curso de Engenharia Ambiental e Sanitária. Atualmente Coordenadora do Núcleo de Pesquisa do Centro de Ciências Tecnológicas - NPT/ CCT. Tem experiência na área de Educação, com ênfase em Educação, atuando principalmente nos seguintes temas: gestão ambiental, educação, química ambiental, didática, meio ambiente, qualidade ambiental da água, solo e sedimento e hidrologia ambiental. 